OPEN ACCESS

Edited by:

Joni Jupesta,

United Nations University, Japan

Reviewed by:

Jay Zarnikau,

The University of Texas at Austin

USA

Payman Dehghanian,

Texas A\&M University, USA

${ }^{*}$ Correspondence:

Paul Burger,

Sustainability Research Group,

Department of Social Sciences,

University of Basel,

Klingelbergstrasse 50,

Basel 4056, Switzerland

paul.burger@unibas.ch

Specialty section: This article was submitted to Energy Systems and Policy, a section of the journal Frontiers in Energy Research

Received: 13 February 2015

Accepted: 28 May 2015

Published: 15 June 2015

Citation:

Burger P, Bezençon V, Bornemann B, Brosch T, Carabias-Hütter V, Farsi M, Hille SL, Moser C, Ramseier C, Samuel R, Sander D, Schmidt S,

Sohre $A$ and Volland B (2015)

Advances in understanding energy consumption behavior and the governance of its change - outline of an integrated framework.

Front. Energy Res. 3:29. doi: 10.3389/fenrg.2015.00029

\section{Advances in understanding energy consumption behavior and the governance of its change - outline of an integrated framework}

\author{
Paul Burger ${ }^{*}$, Valéry Bezençon², Basil Bornemann ${ }^{1}$, Tobias Brosch $^{3}$, \\ Vicente Carabias-Hütter ${ }^{4}$, Mehdi Farsi ${ }^{5}$, Stefanie Lena Hille ${ }^{6}$, Corinne Moser ${ }^{4}$, \\ Céline Ramseier ${ }^{7}$, Robin Samuel, ${ }^{8,9}$, David Sander ${ }^{3}$, Stephan Schmidt', Annika Sohre ${ }^{1}$ \\ and Benjamin Volland ${ }^{5}$
}

\begin{abstract}
'Sustainability Research Group, University of Basel, Basel, Switzerland, '2Enterprise Institute, University of Neuchâtel, Neuchâtel, Switzerland, ${ }^{3}$ Department of Psychology, Swiss Center for Affective Sciences, University of Geneva, Geneva, Switzerland, ${ }^{4}$ Institute of Sustainable Development, Zurich University of Applied Sciences, Winterthur, Switzerland, ${ }^{5}$ Institute of Economic Research, University of Neuchâtel, Neuchâtel, Switzerland, ${ }^{6}$ Institute for Economy and the Environment, University of St. Gallen, St. Gallen, Switzerland, ${ }^{7}$ Center for Energy Policy and Economics, ETH Zurich, Zurich, Switzerland, ${ }^{8}$ Institute of Sociology, University of Bern, Bern, Switzerland, ${ }^{9}$ Social Research and Methodology Group, University of Basel, Basel, Switzerland
\end{abstract}

Transforming today's energy systems in industrialized countries requires a substantial reduction of the total energy consumption at the individual level. Selected instruments have been found to be effective in changing people's behavior in single domains. However, the so far weak success story on reducing overall energy consumption indicates that our understanding of the determining factors of individual energy consumption as well as of its change is far from being conclusive. Among others, the scientific state of the art is dominated by analyzing single domains of consumption and by neglecting embodied energy. It also displays strong disciplinary splits and the literature often fails to distinguish between explaining behavior and explaining change of behavior. Moreover, there are knowledge gaps regarding the legitimacy and effectiveness of the governance of individual consumption behavior and its change. Against this backdrop, the aim of this paper is to establish an integrated interdisciplinary framework that offers a systematic basis for linking the different aspects in research on energy related consumption behavior, thus paving the way for establishing a better evidence base to inform societal actions. The framework connects the three relevant analytical aspects of the topic in question: (1) it systematically and conceptually frames the objects, i.e., the energy consumption behavior and its change (explananda); (2) it structures the factors that potentially explain the energy consumption behavior and its change (explanantia); (3) it provides a differentiated understanding of change inducing interventions in terms of governance. Based on the existing states of the art approaches from different disciplines within the social sciences, the proposed framework is supposed to guide interdisciplinary empirical research.

Keywords: energy-related consumption patterns, behavior change, interdisciplinary framework, governance of individual behavior 


\section{Problem Statement}

It is commonly agreed upon that the transition of the currently existing energy system will require not only technological innovations and substitution of fossil fuels on the supply side but also behavioral changes regarding the individual energy consumption on the demand side. Households, i.e., by definition one or more individuals sharing a living space, consume approximately onethird of the direct energy in Switzerland, mobility not included (BFE, 2014). As individuals are responsible for a substantial share of the total energy consumption, achieving the societal goals of the energy transition also requires reduction of individual energy consumption. Related goals are included in many of the countries' energy strategies (e.g., DECC, 2012), and one of the scientific tasks in the field of energy research is to provide evidence bases on how to achieve the goals of substantially reducing individual energy consumption.

Regarding the latter, there are two main strategies: improving energy efficiency and enhancing sufficiency. So far, however, there is no great success story to be told regarding the aspired reduction. Despite many efforts, there is no clear evidence that the total energy consumption of individuals has been reduced substantially during the last decade. In Switzerland - comparable to other industrialized countries - the total final energy consumption of private households in 2012 exceeded the consumption in 2000 by $4.5 \%$, instead of the intended decrease (BFE, 2013:5). A number of related barriers have been identified in numerous scientific studies and they include a lack of information and motivation to reduce energy consumption, energy as a quasi invisible factor, relatively small financial incentives for energy saving compared with firm daily routines, symbolically loaded activities, or specific decision heuristics etc. (Reddy, 1991; Shove, 1997; Lorenzoni et al., 2007; Steg, 2008). Additionally, rebound effects have counteracted realized efficiency gains (cf. Greening et al., 2000; Darby, 2007; Herring and Roy, 2007; Sorrell et al., 2009; Van den Bergh, 2011). Economists tend to refer to the "energy efficiency gap" to explain the meager success (Jaffe and Stavins, 1994; Gillingham and Palmer, 2014). Advocates of sufficiency strategies complain about the one-sidedness of efficiency and argue that only combined strategies will lead to the intended reduction goals (Sachs, 1993; Darby, 2007; Notter et al., 2013). In addition to individual barriers, there are also frame conditions that strongly influence behavior patterns but over which individuals have little influence (Scheuthle et al., 2005). These conditions include among others the persistent effects of existing appliances, the landlord/tenant dilemma, availability of facilities, market, and policy failures, as well as social norms and conventions. To some extent, there is certain progress in changing behavior and research has shown that with adequate measures (e.g., individual consulting, commitment strategies, campaigns making use of social norms etc.) applied at the right time (e.g., windows of opportunity where habits can be broken), behavior can actually be changed (Nolan et al., 2008; Schäfer et al., 2012; Baca-Motes et al., 2013). However, societies are not yet really on track with the ambitious goals they aspire to. It seems that both our understanding of the determining factors of energy-related consumption and our understanding of the drivers and barriers of change need to be improved for making progress toward reduced energy consumption in households.

The distinction between understanding behavior and understanding change of behavior has been introduced on purpose. Unfortunately, these two explanatory goals are not always kept separate in the literature. The first explains energy consumption behavior (ECB) as it is today, and the second explains its change. As this distinction is decisive and allows us to unfold the different scientific tasks, we start with looking at it more closely.

Because any explanation is composed of two elements, namely of what has to be explained (the explanandum) and what it is explained with (the explanantia), the first goal of "explaining ECB" implies answering the following two questions:

\section{(1) What is ECB?}

(2) Which factors determine ECB?

Question (1) is by no means trivial. An economist for example could easily say that it is a demand function we are looking for. But does this denote demand for energy or demand for energy services (as we will argue for)? And does "demand" capture e.g., the daily routines in consuming embodied energy? An explanation is basically dependent upon what is to be explained. As a description of the components of ECB is far from being evident, answering question (1) is a first indispensable step toward clarifying the research object (explanandum). Question (2) then addresses the explaining factors of the behavior in question (explanantia).

However, explaining "ECB" includes neither the temporal dimension of change nor the reduction goals. Hence, there is a second explanatory goal, namely explaining "change of energy consumption behavior toward reduction" (cf. also Darnton, 2008 for distinguishing two explanatory endeavors). Accordingly and following the above made distinction between explanandum and explanantia, two further questions can be formulated:

\section{(3) What is "change of ECB?" \\ (4) Which factors explain changes of ECB?}

As with question (1), answers to question (3) are not as straightforward as it first may seem. First, answers are dependent on the approach chosen for question (1). For example, it makes a huge difference whether embodied energy is included or not. Second, a clear definition of the scope of "change" is mandatory. Are we simply talking in terms of reduced $\mathrm{kJ}$ on the individual level or do we broaden "change" to capture a changed perception of what makes up quality of life (cf. Mourik and Rotmann, 2013)? Hence, analyzing behavior and analyzing its change force us to first clarify the object of interest (explanandum).

Question (4) also asks for clarification, as the term "factors explaining changes" (explanantia) could be interpreted in two ways. First, it can refer to those factors that explain behavior according to question (2). We will argue below that the types of factors are the same as in question (2), e.g., including milieu related aspects, decision heuristics, spontaneous developments, norms etc. As different behaviors ask for different determinants, we need to identify the variation of the factors within the types. Second, "factors" can also refer to interventions, political instruments etc., i.e., 
to elements directed to steer behavior toward a change. However, we do not use the term "factor" in that second sense. Instead, we propose to add a fifth question:

(5) What are the constituents to be taken into account to successfully govern change of energy-related consumption behavior?

Question 5 deals with the realm of governance. And again, answers are not as straightforward as it seems. Given the complex scientific debate on "governance of societal change," it is worth considering this topic and refraining from an exclusive focus on political instruments.

An abundance of literature already contributes to many aspects within the sketched explanatory fields. Whether the current state of the art, however, copes with the indicated distinctions and their inherent complexity is at least doubtful. Despite the large number of scientific studies, science still struggles with understanding ECB and the triggers for changing it. Existing scholarship has for example so far been largely dominated by studies on price sensitivity, "rational actor"-models, drivers and barriers for accepting new technologies, and rebound effects. Studies on socio-cultural aspects (e.g., milieu, lifestyles) or on routines can be found only to a much lesser extent. Moreover, recent psychological and consumer behavior research has pointed to other factors such as cognitive heuristics, emotions, moral and social norms, and personal core values (Kahneman, 2003; Brosch and Sander, 2013). In addition and most importantly, the scientific state of the art displays strong disciplinary splits (Keirstead, 2006) to the effect that there is only little understanding of the interrelations among different aspects of ECB across the different fields such as psychology, economics, and the social sciences. Against the backdrop of the existing difficulties for answering questions (1)-(5) and the dominant disciplinary splits, we see at least six expectations motivating this paper's undertaking to establish an integrated framework for analyzing ECB and its change:

(1) Facing the complexity and the patchwork-character of consumption and related explanations, capturing the interplay between different domains, e.g., social segmentation and decision heuristics or governance and emotional factors, becomes an important task. Stern (2014) (p. 44) puts the point nicely: "Researchers adhering to a disciplinary approach often fail to examine the possibility that these variables may matter more for some choices than others, that they interact with other factors [...], and particularly that they may not matter much for the household choices that have the greatest implications for overall energy use." Only by bringing together the manifold factors will we be able to provide well-founded evidence for societal decisionmaking. (2) Given the aggregated reduction goal, comparisons between as well as aggregation over the different subsectors of consumption with their different explanations and different settings for behavioral changes are needed - presupposing a common basis. (3) Additionally, the variations in ECB direct us toward taking a closer look at the demand side and disentangling the very broad notion of "demand," among others in looking at well-being aspects linked to demand. (4) The two explanatory tasks - explaining ECB and explaining its change - are often confounded within the literature. An interdisciplinary framework could help clarify the different tasks by not only cutting clean but also by integrating these two explanatory perspectives; bringing different disciplinary competences together. (5) The potential of governance to steer ECB remains unclear. As modern energy consumption patterns are diverse, certain governance means could have different impacts on different consumption sectors for different individuals (Owens and Driffill, 2008). Moreover, individuals are normally addressed by complex sets of steering measures. How these different policies interplay with each other is hardly understood so far (Oikonomou and Jepma, 2008). (6) There are strong variations across disciplines in terms of theories and methods. Different theories and different methods capture different aspects of a field and hence, can be brought together, e.g., for triangulation or complementary insights.

We expect an interdisciplinary framework to offer a systematic basis for linking the different aspects and supporting the different disciplines to learn from the strengths of the others to provide more integrated results. It could support paving the way to address the intersections between different factors, providing a basis for comparisons and aggregation and for disentangling the demand side, distinguishing between different explanatory tasks, having all available scientific competences regarding the different explanatory facets, and collecting disciplinary competences for triangulations and the like. Some integrated models have already been set up in (more or less) interdisciplinary approaches [cf. Section "Paving the Way Towards an Integrated Framework (Relevance and Gaps)"]. While recognizing the instruction value of these models, we nevertheless follow Wilson and Dowlatabadi's (2007) statement that there is still an academic gap regarding integrated, interdisciplinary models or frameworks that systematically capture the different explanatory tasks regarding ECB and its (governed) change. Our paper contributes to closing this gap.

Last but not least, there is a practical add-on. The authors are all members of the work package on change of behavior within the newly founded Swiss Competence Center for Research in Energy, Society, and Transition (SCCER-CREST) ${ }^{1}$. We expect the proposed framework in this paper to not only guide our particular research toward the commonly defined goals, namely, providing empirical evidence for business, political, and civil society actors on the change of ECB, but also to provide a general guidance for the research undertaken in SCCER-CREST (Krysiak and Weigt, 2015).

\section{Paving the Way Toward an Integrated Framework (Relevance and Gaps)}

Most of the already suggested integrated frameworks try bringing together insights from different disciplines to understand ECB. There are at least three different types of such frameworks. The first tries to capture the field as a socio-technical system, bringing in social and engineering sciences. Hitchcock (1993) for example, distinguishes between the physical and the human subsystem each containing trigger points for either technical or social change. The second is mainly oriented toward economic modeling that pays attention to interaction between macro and micro factors.

${ }^{1}$ http://www.sccer-crest.ch 
Dholakia et al. (1983) e.g., argued that micro choices of the individuals (social, psychological factors) are delimited and defined by macro choices (political, economic factors); the latter (e.g., settlement structures) being often more relevant than the former. A third type tries to represent the different factors by basically relying on some specific theory from sociology. Wilk (2002) and Keirstead (2006) suggested interdisciplinary frameworks based on sociological approaches from Bourdieu, or Actor Network Theory (ANT) linked with Agent Based Modeling. There are also blends such as Stephenson et al. (2010), which also rely on ANT but otherwise develop their "energy cultures framework" strongly on the basis of Lutzenhiser (1993) cultural model of household energy consumption. Interpreting ECB as interactions between cognitive norms (e.g., beliefs, understandings), material culture (e.g., technologies), and energy practices (e.g., activities and processes), Stephenson et al. could be read as merging types one and three. However, there are obviously some important caveats. First, there is a gap between economics and the other types. Second, all rely on some disciplinary, partly contested theory. Third, governance of change is often only represented by the very general category "intervention," leaving it as a black box.

Indisputably and again following Wilson and Dowlatabadi (2007), an interdisciplinary framework should succeed in integrating the best conceptual and empirical basis already created by scholars within the contributing disciplines. To cope with this requirement, we want to look at the existing state of the art in the disciplines we represent, i.e., psychology, economics, consumer behavior, business science, sociology, and political science. We shortly present their basic findings and major existing knowledge gaps in the following.

\section{ECB and its Change from a Psychological Perspective}

Psychology differentiates between single-shot energy-related decisions (such as purchase of energy-efficient appliances) and everyday energy-related behaviors such as showering behavior or commuting that are, to a larger extent, characterized by automatic habits and routines, and may thus be differentially influenced by psychological factors (Breukers et al., 2013). Psychological approaches in general emphasize the importance of factors such as belief structures, value systems, attitudes, emotions or social norms on energy-related decisions and behaviors (Ajzen, 1991; Stern, 2000). The Theory of Planned Behavior (TPB, Ajzen, 1991) assumes that decisions and behaviors are the consequence of a process that weighs the costs and benefits of the behavior, taking into account the factors attitude toward the behavior, perceived behavioral control and norms held by important reference people. TPB has been successfully used to predict a wide range of behaviors, including energy-relevant behaviors such as energy savings (Harland et al., 1999) or choice of transportation (Bamberg et al., 2003). As a "rational choice"-theory, TPB conceptualizes individual decisions as driven by cognitive processes underlying self-interested utility maximization. Value-Belief-Norm Theory (VBN, Stern, 2000) has been developed with the aim to explain altruistic behavior. VBN proposes a causal mechanism focused on individual core values. These values are broad representations of an individual's overarching goals that guide the evaluation and selection of behaviors in many different contexts (Rohan, 2000). Different value bases may drive energy-saving behavior: self-interest values may lead to energy-saving behavior because of the consequences for one's own well-being, a perspective consistent with the economic rational actor model; social altruism values refer to concerns about a larger circle of individuals, possibly extending to all mankind; biospheric altruism values refer to concerns about all living species and the state of ecosystems, beyond the potential benefits to human life. VBN has been used to successfully predict a number of energy-relevant decisions and behaviors, such as intentions to reduce car use (Nordlund and Garvill, 2003) or to recycle (Guagnano et al., 1995). Recent research has furthermore investigated the role of emotions in energy-relevant behavior, illustrating that an individual's emotional reactivity in environmentally relevant situations is a good predictor of intentions to reduce energy use (Brosch et al., 2014).

Furthermore, psychological theories take into account that individual energy consumption is shaped by its social context. This is of particular relevance when explaining behavior change. Social influences on changes regarding energy consumption patterns were demonstrated empirically for different types of energy services. For example, a series of field experiments in California indicates that household electricity consumption can be reduced by providing households with feedback about their own consumption and about the average consumption in their neighborhood (Schultz et al., 2007). Two different types of social norms have been shown to be important for promoting electricity savings; descriptive norms (i.e., feedback about average consumption in the neighborhood) and injunctive norms for preventing below-average consuming households to increase consumption (i.e., evaluation of own consumption relative to neighborhood consumption by means of the icons 9 or $\Lambda$ ). The mentioned effects could be replicated in different studies, and the effects have shown to be long-lasting (up to 12 months, Ayres et al., 2013). Thus, energy consumption feedback including a social, competition-like situation seems to be a very promising approach (see also Abrahamse et al., 2005). In the domain of transport, an important determinant of individual bicycle use is the existence of a cycling culture within the community; the more people use bicycles, the more attractive this behavior is also for other individuals (Goetzke and Rave, 2011). Reasons for this are informative (e.g., people see each other cycling and talk about the benefits) but also normative (e.g., norms that cycling is healthy and ecofriendly, conformity pressure).

From a psychological perspective, ECB represents the result of a complex interplay between individual factors such as attitudes, values, emotions, and know-how, as well as social rules and norms. Accordingly, psychological approaches should be complemented by other disciplines in order to contribute insights for ECB. Close interdisciplinary collaboration is needed to fill the following research gaps:

- understanding the complex interplay of psychological, socio-demographic/economic, and spatial factors to explain energy-related decisions and behavior (further necessary disciplines: sociology, geography);

- analyzing the most promising interventions to change 
behavior in terms of energy-saving potentials and social acceptance (further necessary disciplines: behavioral economics, sociology, environmental engineering);

- linking the governance and the individual level when designing interventions to change individual level (further necessary disciplines: policy sciences).

\section{ECB and its Change from an Economic Perspective}

In accordance with standard consumer theory, the analysis of ECB in economics starts from the assumption that individuals or households choose their demand for energy services as part of a consumption bundle that maximizes their utility subject to budget and information constraints. Energy services are produced by the households using capital and energy inputs. Observable demand for energy inputs such as gas, oil, or electricity is therefore "indirect" in the sense that it is not only based on preferences and constraints, but also on available technologies that convert energy inputs into energy services. An important notion of the general equilibrium theory that informs economic analysis is that changes in determinants of behavior automatically lead to adjustments in behavior. For this reason, economics lacks a stringent differentiation between determinants of behavior and determinants of behavioral change.

Following the discipline's strong focus on constraint-based explanations of consumer behavior, empirical research into energy consumption has focused overwhelmingly on the effects of prices and income. It has demonstrated that variation in energy prices accounts for a substantial share of variation in demand. Moreover, it has shown that long-term adjustments to price changes (i.e., price elasticities) are substantially larger than short-term adjustments, suggesting that energy prices are important determinants of investment decisions into energy efficient household appliances and home improvements (e.g., Khazzoom, 1987; Durham et al., 1988; Van den Bergh, 2008). Accordingly, price-based instruments (taxes, subsidies, differentiated rates) are considered to be the most effective and efficient policy measures to achieve socially optimal energy use patterns (Gillingham et al., 2009; Linares and Labandeira, 2010; Gillingham and Palmer, 2014). Similarly, research suggests that information provision can help in improving consumer decisions with respect to direct energy demand (Abrahamse and Steg, 2009) and investment in energy-efficient household appliances (Deutsch, 2010; Heinzle, 2012; Ölander and Thøgersen, 2014).

Other, less conventional factors of energy demand like social considerations, pro-environmental attitudes, risk aversion, or feelings of guilt have been incorporated into the utility approach by assuming that they can be modeled as arguments in the individual's utility function (Kotchen and Moore, 2008; Jacobson et al., 2012; Lange et al., 2014). Differences in incentive structures have also been identified as barriers to socially optimal energy demand. For instance, it has been shown that owners and renters differ substantially with respect to energy use and investment in energy-efficient durables (Davis, 2012; Gillingham et al., 2012). Finally, a wealth of recent research has demonstrated that decisions on energy use are partly driven by automatic and unconscious processes like preference learning, time inconsistencies, framing effects, and decision heuristics, which contradict the assumption of a consistent utility-maximizing individual (Sunstein, 2015; Pollitt and Shaorshadze, 2013; Ölander and Thøgersen, 2014).

While the economic approach to household energy demand has been widely successful in explaining patterns of price and income effects, less progress has been made in understanding determinants of behavior and behavioral variation beyond variations in budget constraint and information. Integrating theories and findings from other disciplines may, thus, substantially improve our understanding of household behavior and may shed light on important interactions between economic and non-economic determinants of energy demand. Such insights may help to address some of the following research gaps:

- understanding the considerable variation in household responses to economic policy incentives, such as subsidies for energy-efficient retrofits, differentiated tax rates, social nudges, or energy labels;

- extending the analysis of social reward and social comparison mechanisms in determining energy consuming behaviors and the adoption of innovations;

- investigating the interactions between intrinsic motivations, social nudges, and economic policy incentives in households' energy-conservation efforts. Specifically, understanding the conditions under which policy incentives and social nudges reinforce rather than undermine intrinsic motivations;

- complementing the empirical analysis of household energy demand by accounting for the indirect energy embodied in the supply chain of products and services consumed by the household;

- evaluating the effectiveness of different energy conservation policies considering the complex interplay between direct and indirect energy demand. This is particularly important for a comprehensive understanding of the long-term consequences of efficiency-induced income expansions or savings (e.g., rebound effect).

\section{ECB and its Change from a Consumer Behavior Perspective}

Thriving as an independent field at the interface between behavioral economics and psychology, Consumer Behavior has originally emerged as a sub-discipline of marketing. At its core, it involves "the study of people operating in a consumer role involving acquisition, consumption, and disposition of marketplace products, services, and experiences" (MacInnis and Folkes, 2010). Being a multidisciplinary field that encompasses perspectives and blends elements from a multitude of different disciplines, including economics, sociology, political science, and others, academic research in the consumer behavior field has further developed from limiting its focus to marketing management to also taking a broader angle by integrating a societal and public policy perspective that also involves examining consumers' choices outside the conventional company-customer purchase context (MacInnis and Folkes, 2010).

The consumer behavior field has seen the emergence of many different specializations. One of the sub-disciplines is the Behavioral Decision Theory that deals with, among other things, heuristics and biases (MacInnis and Folkes, 2010). The starting point of this research stream is that in reality, consumers often 
simplify their decisions by relying on decisions strategies that can be described as simple "rules of thumb" (Thaler and Sunstein, 2008). Heuristics often speed up the decision-making process and produce sensible judgments and behavior. However, applying heuristics can also lead to systematic errors, or so-called "cognitive biases." Classic specific cognitive biases include framing effects, loss aversion, status quo biases, or hyperbolic discounting, just to name a few. Research on heuristics and biases can noticeably contribute to a better understanding of the energy-conserving behavior of consumers. For instance, research on the status quo effect has shown that when consumers are presented with a utility bill that contained a default choice, most consumers would be reluctant to change it (Brennan, 2007). In a similar vein, McCalley (2006) showed that the default setting of the washing machine leads to significant differences in the energy used. In addition, research on heuristics can also contribute to the long-standing debate about the commonly cited "energy efficiency gap." Many scholars have investigated measures to limit this gap, including the introduction of energy labels or providing information with regard to future operating costs (e.g., Kaenzig and Wüstenhagen, 2010). Nevertheless, research related to framing has revealed that not only the provision of such information but also the framing of such information (e.g., design of energy labels) impacts decisionmaking (e.g., Heinzle, 2012; Heinzle and Wüstenhagen, 2012; Meissner et al., 2013; Ölander and Thøgersen, 2014).

In another specialization of consumer behavior research, different scholars studied characteristics of eco-conscious consumers including demographics, psychographics, and behavioral variables (e.g., Straughan and Roberts, 1999; Do Paço and Raposo, 2009). In addition, there is a vast amount of literature in the consumer behavior field devoted to examining the effectiveness of softer motivators applied by social marketers to foster energy conserving behavior, including social norms, commitment strategies, prompts, or soft nudges (e.g., Aronson and O'Leary, 1982; McCalley, 2006; Goldstein et al., 2008; Schäfer et al., 2012; Baca-Motes et al., 2013; Burchell et al., 2013; Sunstein and Reisch, 2013). Other streams of research are devoted to analyzing new less resource-intensive models of consumption such as collaborative consumption (e.g., Botsman and Rogers, 2010; Belk, 2010; Ozanne and Ballantine, 2010; Bardhi and Eckhardt, 2012) and the relationship between materialism and happiness (e.g., Burroughs and Rindfleisch, 2002). Last but not least, another field of research is devoted to analyzing possible side effects of adoption of single energy conserving behaviors, including positive spill-over effects or moral licensing (e.g., Tiefenbeck et al., 2013). There is clearly a need for further research in this area to determine (a) whether evidence for moral licensing is widespread in different contexts and (b) whether the effect is only a short-term phenomenon.

Despite being already a multi-disciplinary field, consumer behavior research could collaborate with other disciplines in order to contribute to a more comprehensive understanding of consumer behavior related to energy conservation. For instance, cooperation would be fruitful in order to contribute to the subsequent research gaps:

- investigating the role of the effectiveness of governmental incentives and new financing models (e.g., leasing) in order to address the energy efficiency gap (collaboration with disciplines: finance and political sciences);

- investigating the role of social approval motivations and the effectiveness of social rewards (e.g., free use of bus lanes with electric vehicles) regarding the adoption of innovations (collaboration with disciplines: psychology and sociology);

- investigating the role of computing and information technology to reduce energy consumption (collaboration with disciplines: information and computing technology);

- investigating the role of misleading green claims on consumers' trust to purchase green products and designing effective interventions/laws to reduce green-washing (collaboration with consumer law);

- better understanding of adoption of innovations by visualization of peer effects (collaboration with disciplines: geography and sociology);

- better investigation of the information processing effected by the brain related to heuristics and biases (collaboration with disciplines: psychology, behavioral economics, and neuroscience).

\section{ECB and its Change from a Business Science Perspective}

The business science is more focused on the energy consumption of businesses than that of individuals. As a result, the literature is rather scarce on the impact of businesses and managerial decisions on ECB, especially in terms of integrative models or theories. The relevant literature can be structured in three main disciplines: marketing, innovation management, and operations research.

First, marketing is by nature more interested in changing or maintaining behaviors than in explaining behaviors (the latter is covered by the consumer behavior perspective). Marketing research on energy conservation programs highlights the importance of making transparent the information about price (Rudelius et al., 1984), the lack of data on energy consumption that limits the programs' effectiveness (Hirst, 1980), the need to segment the market and how to do it (Allen et al., 1982; Downs and Freiden, 1983; McDonald et al., 2012), as well as factors that prevent sustainable energy consumption, categorized into policies and regulation, product accessibility and availability, pricing, and customer knowledge (Press and Arnould, 2009). Those researches are usually relevant for public or non-profit organizations that design marketing programs to stimulate energy conservation and, in specific situations, for private companies [see for instance Harvey and Kerin (1977)].

Second, innovation management research has investigated ECB mostly through cluster management, product design, and diffusion of innovation. Similar to marketing, research on innovation management has analyzed the impact of innovation-related decisions or actions on change in energy-related behaviors rather than on explaining those behaviors. For instance, innovation centers play an important role to reduce energy consumption in cities (Foley et al., 2011; Baydoun, 2013). Innovation management research also shows that innovative product design and design process have indirect effects on individuals' consumption (Cainelli and Mazzanti, 2013; Favi et al., 2014). For instance, 
Shrestha and Kulkarni (2012) find that product design (using the case of homes and appliances) needs to take into account homeowners' lifestyle and comfort level to reduce energy consumption levels more effectively. Studying the role of sustainability initiatives, Susskind (2014) finds that subtle in-room energy reduction does not decrease consumer satisfaction. This highlights the potential for businesses to reduce individuals' energy consumption through service design while incurring a cost benefit without depreciating satisfaction. Finally, energy-efficient innovations are usually not enough to reduce ECB (Herring and Roy, 2007). Innovations and a better understanding of the factors of their adoption as well as the promotion of sustainable lifestyles must be combined to avoid rebound effects.

Third, operations management research related to ECB has rather focused on demand forecasting (modeling demand) than on how to reduce demand (changing demand). For instance, energy demand models have been developed in the natural gas (Brabec et al., 2008) or electricity sectors (e.g., Charlton and Singleton, 2014; Haben et al., 2014). However, some research also highlighted possibilities to reduce consumption: Loock et al. (2013) highlight how information systems can stimulate individuals' energy conservation through the use of a goal setting functionality, default goals, and a feedback mechanism.

Although some researchers have investigated the impact of organizations on ECB from a business or managerial perspective, there are gaps in the literature, many of which require cooperation across disciplines to be filled. Examples of gaps and potential for cross-disciplinary collaborations include the following:

- understanding the overall impact of businesses and managerial decisions on ECB, in particular related to embodied energy (economics, psychology);

- understanding business influence to changes in ECB. Concepts such as the circular economy (see for instance SATW, 2014), service co-production (Auh et al., 2007), and corporate social responsibility initiatives to reduce individuals' energy consumption could foster innovative ideas as they hold potential to also benefit companies (economics, psychology, sociology);

- understanding governance mechanisms and incentives that stimulate businesses to reduce energy consumption at the household level (political science, economics).

\section{ECB and its Change from a Sociological Perspective}

If we understand the use of energy services as consumption, three sociological ways of studying ECB may be identified. The first strand conceives of consumption as a means to express identity, often within a post-structuralist framework (e.g., Bauman, 2001). Work in this strand centers around what came to be called the "communicative paradigm" (Soron, 2010, p. 175), which is interested in the symbolic meanings of consumption. ECB is explained as being rooted in shifting modes of how people construct their identities in individualized and consumerist societies. A second strand conceptualizes consumption as a moment of practice that reproduces hierarchies and acts as a marker of milieu membership (Bourdieu, 1979; Giddens, 1991; Veblen, 2007). From this perspective, factors of energy consumption are milieu or class specific consumption patterns that are shaped by the distribution of various resources and embedded in practices. A third strand revolves around different adaptations of rational choice theory (RCT; Coleman, 1986). RCT has been employed by various disciplines to investigate behavior that is relevant to sustainability and the use of energy services. Here, ECB is an outcome of people trying to maximize utility functions. This approach is fruitful when the aim is to develop causal explanations of micro level behavior and its effects on the macro level (Lovett, 2006; Liebe and Preisendörfer, 2010).

In the context of this paper, the second strand appears to be most relevant as it implies looking at how high level structures affect low level structures and vice versa while allowing for a rich contextual understanding of energy consumption. This approach aims to balance structure and agency by looking at how the distribution of various resources, such as economic capital and knowledge, affect individual energy consumption and thus the potential to attain well-being (Jackson, 2005). A basic assumption is that consumption creates identity, distinction, and status (see Bourdieu, 1979). Various processes, however, such as falling prices through productivity gains, diminish the distinctive power of food and appliances (Thøgersen, 2005). Hence, people consume more and more exclusive products to distinguish themselves from others. Every-day routines without much distinctive power, for example taking a shower, also prove to be important drivers of energy consumption (Jackson, 2005). An important body of literature emphasizes the relevance of these inconspicuous routines and habits to consumption patterns (Southerton et al., 2001; Shove, 2003). Consumer culture and "keeping up with the Joneses dynamics" lead to more resource intensive standards of living (Southerton et al., 2001). ECB is then understood as a moment of social practice and changing ECB will require transforming social practices (Warde, 2005; Walker, 2014).

Yet, there have been no attempts to systematize and conceptualize energy relevant routines and conventions of individual energy consumption patterns and its change in the sociological literature. To advance the sociological understanding of ECB and its change, insights generated by other disciplines are necessary to:

- elucidate the level of the individual, e.g., the social consequences of breaking habits via disruption and the effects of financial incentives (psychology, economics);

- understand how modes of governing energy behavior may affect societal structures and their incumbents, e.g., through transformations of contextual factors that may shift practices (political sciences).

\section{Governance of ECB from a Political Science Perspective}

Political science is not concerned with explaining individual behavior, but steering individual behavior and its change are important issues. However, in the field of energy policy research, most analyses focus on the aggregated societal, economic, environmental, and technological effects of certain energy policy schemes (e.g., Lewis and Wiser, 2007; Lipp, 2007; Carley, 2011; Delmas and Montes-Sancho, 2011). Only a few contributions are specifically 
concerned with the political steering of ECB (e.g., Lindén et al., 2006; Owens and Driffill, 2008; Gyberg and Palm, 2009). In any case, the development within the discussion on political steering needs to be taken account of in research on governance of ECB.

The classical literature pertaining to political steering focused on the analysis of the design and implementation of policy instruments as well as their impacts and outcomes (Hood, 1983). Successful steering was mainly seen as a matter of rationally designing policy instruments that affect the behavior of collective (firms, organization, groups) and individual actors according to a set of steering goals defined by the state. This has yielded a differentiated understanding of the functioning of various types of policy instruments - "carrots, sticks, and sermons" (BemelmansVidec et al., 2011) - as well as of their general effectiveness and efficiency (Vedung, 2007). However, this focus on state defined policy instruments became questioned. First, the dominant rationality assumption turned out to be flawed. Empirical studies showed that the design and implementation of policy instruments and thus their success and failure were affected by multiple contextual factors, such as power relations, values, beliefs, acceptance etc. (Linder and Peters, 1989; Schneider and Ingram, 1990; Howlett, 1991; Hill and Hupe, 2002). Second, the steering paradigm was criticized for its unrealistic division between the state (steering subject) and the society (steering object). Empirical studies showed that there are also societal actors who actively shape the goals and means of steering (Mayntz et al., 1978; Bardach, 1979; Sabatier, 1986). Finally, advocates of liberalism argued that the steering deficits were in fact "government failures" and opted for regulations on grounds of market principles. Moreover, participatory democrats interpreted the steering failures in terms of "democratic deficits," and thus called for the empowerment of citizens and the establishment of community-based settings of "self-help" (for energy-related issues, see, e.g., Kellett, 2007).

These criticisms gave rise to a more fundamental paradigm change in steering theory (Eliadis et al., 2005). The new "governance" concept rejects the idea of an omnipotent state, which rationally designs and implements policy instruments in a topdown manner. And it questions the adequacy of both the liberal and participatory alternative. Political steering is seen to involve state, market, and societal actors who set and coordinate their individual action courses in complex settings of different governance mechanisms. It is neither pure state hierarchies, nor liberal markets or citizen communities that organize collective action, but context-specific mixes of them (Salamon, 2002; Pierre and Peters, 2005; Howlett, 2009, 2011). From this perspective, steering societies is about the design of complex governance arrangements by combining elements of policy, politics, and polity ${ }^{2}$ in a systematic, but problem-related manner (Lange et al., 2013; Voß et al., 2006).

Whereas the "governance turn" in steering theory came with a focus on the organization of collective action, the "individual" has recently been re-discovered in political science, especially under the term "nudging" (Thaler and Sunstein, 2008; Jones et al., 2014).

2Political science distinguishes among these three dimensions, i.e., "polity" as political structures, "politics" as procedures and "policy" as contents (e.g. March and Olsen, 1983; Schubert and Klein, 2011).
The core of this idea is to shape the behavior of individuals without normatively forcing, economically stimulating, or morally pushing them. Instead of using visible "carrots, sticks, and sermons," individuals are addressed with invisible "nudges": unconscious modulations of their choice architectures. "Nudging" broadens the range of options for steering individual behavior based on the latest insights in behavioral sciences. However, apart from the need for further conceptual (Selinger and Whyte, 2012), normative (Vallgårda, 2012; Fischer and Lotz, 2014), and functional reflections (Schnellenbach, 2012), the discussion seems to fall back behind the insights of the governance turn in steering as it tends to neglect the embedding of nudges in complex institutional and procedural settings.

Against the backdrop of the developments in the general discussion about political steering, there are good reasons to frame the challenge of steering ECB in terms of a governance perspective. Governance of ECB is about the design of complex governance arrangements: institutional settings in which multiple actors coordinate their multiple policy interventions. In light of this basic understanding, two routes seem to be of particular relevance for a collaborative research agenda on the governance of ECB:

- the governance perspective broadens the focus on "instruments," which is prevalent in the other disciplines related to ECB and highlights the need for an embedded analysis of these instruments;

- to better understand the functioning and impact of complex governance arrangements on ECB, political science would benefit from the insights of the other disciplines with regard to the multiple factors that determine ECB and its change.

\section{First Synthesis: Categories, Gaps, and Challenges}

Obviously, there are both a rich body of scientific knowledge as well as a remarkable amount of knowledge gaps. The next step in developing a framework consists in trying to substantiate what has been sketched such that we can see in what respect the different disciplines provide answers to the five stated questions. In addition, it is also of interest to capture the different desiderata mentioned within the state of the art's descriptions. In what follows we restructure the given descriptions along first their answers to questions (1) and (3) (expressing the two objects of explanations, i.e., the explananda; cf. table 1), then second their answers to questions (2) and (4) (expressing the candidates for explaining the behavior and its change in questions, i.e., the explanantia; cf. table 2), and finally the answers on question (5) (cf. table 3).

(1) \& (3): political science does not contribute to explaining behavior but only to its change (Table 1). The other disciplines often refer to "energy services"; however, there are obviously some variations and different foci. It is far from being evident that "decisions," "demand," and "use" have the same meaning. They could well express different aspects of the behavior. Many studies in the field still do not operationalize "use of energy services" for their research and only look at the amount of used primary energy [for a discussion on this, see Jonsson et al. (2011)]. Moreover, analyses of ECB often focus on specific sectors of direct use such as electricity, thermal energy for housing, and fuel energy for transport. 
Energy consumption patterns within domains of "embodied" or indirect energy use such as food, clothing, leisure activities etc., are analyzed to a lesser degree. This has been highlighted several times. Collecting the main elements given above, we can gain the following picture regarding questions (1) \& (3).

In addition, the literature contains more detailed distinctions concerning (1) \& (3). One can find, for example, purchase or investment compared to daily application (instead of single-shot and routines, cf. Breukers et al., 2013). Bergius (1984) classifies material-specific (e.g., purchase) and action-specific (e.g., usage) behavior; Van Raaij and Verhallen (1983) distinguishes between purchase, usage, and maintenance behavior. Further criteria for characterizing the explanandum can be areas of life (home, work, spare-time) or starting points for energy saving behavior. Some approaches explicitly take "environmental friendly" behavior as expressing our "change of behavior" (Wilson and Dowlatabadi, 2007). Obviously, we need not only to distinguish between "explaining behavior" and "explaining change of behavior," but also we also need to establish a precise common understanding of what we want to explain.
(2) \& (4): collecting and structuring the proposed explanantia as well as considering the desiderata addressed above, we achieve again a complex and multi-variant picture (Table 2): first, Political science does not offer explanantia as they are not analyzing behavior. They contribute to governance related factors to be captured in Table 3. Second, there are again some disciplinary overlapping or similarities but also differences. Each discipline refers to a set of explaining factors that include mental (e.g., decision heuristics) and some sort of social factors (e.g., norms). This is fully in line with Darnton (2008) who argued that understanding the dynamic of consumption transcends a division between internal (mental) and external (societal) factors. Some of these factors like emotions, however, have only been included rather recently in research agendas. And though the disciplines have their foci such as income or decision heuristics, they also strive to consider the interplay with other factors. Exciting research desiderata are mainly identified regarding our understanding of how the different factors interact. Third, business science, consumer behavior, and sociology point to social segmentation as a potentially explaining factor, whereas the economists refer to unexplained variations in behavior. In what

TABLE 1 | Explananda in the foci of the different disciplines.

\begin{tabular}{|c|c|c|c|c|c|c|}
\hline & Psychology & Economics & Consumer behavior & Business science & Sociology & Political science \\
\hline $\begin{array}{l}\text { Question (1): } \\
\text { explanandum } \\
\text { "ECB" }\end{array}$ & $\begin{array}{l}\text { Single-shot energy-related } \\
\text { decisions and routines; } \\
\text { rational (utility oriented) } \\
\text { and altruistic behavior }\end{array}$ & $\begin{array}{l}\text { Demand for energy } \\
\text { services; part of } \\
\text { consumption bundle; } \\
\text { maximizing utility }\end{array}$ & $\begin{array}{l}\text { Acquisition, consumption, } \\
\text { and disposal of products, } \\
\text { services, experiences }\end{array}$ & $\begin{array}{l}\text { Demand for energy } \\
\text { (forecasting purpose) }\end{array}$ & $\begin{array}{l}\text { Use of energy } \\
\text { services; ECB as a } \\
\text { moment of practice }\end{array}$ & $\mathrm{N} / \mathrm{A}$ \\
\hline $\begin{array}{l}\text { Question (3): } \\
\text { explanandum } \\
\text { "change of } \\
\text { ECB" }\end{array}$ & $\begin{array}{l}\text { Change of individual } \\
\text { behavior or decision } \\
\text { patterns }\end{array}$ & $\begin{array}{l}\text { Reducing } \\
\text { overall individual } \\
\text { consumption }\end{array}$ & $\begin{array}{l}\text { Change of individual } \\
\text { consumer behavior }\end{array}$ & $\begin{array}{l}\text { Change of consumer } \\
\text { behaviors; reduction } \\
\text { of embodied energy in } \\
\text { products and services }\end{array}$ & $\begin{array}{l}\text { Change as } \\
\text { transformation of } \\
\text { practices }\end{array}$ & $\begin{array}{l}\text { Change of } \\
\text { individual behavior } \\
\text { in light of collective } \\
\text { goals }\end{array}$ \\
\hline Desiderata & $\begin{array}{l}\text { Better understanding } \\
\text { the complex relations } \\
\text { of psychological, socio- } \\
\text { demographic/economic, } \\
\text { and spatial factors }\end{array}$ & $\begin{array}{l}\text { Focus on single } \\
\text { sources like } \\
\text { electricity; embodied } \\
\text { energy missing }\end{array}$ & $\begin{array}{l}\text { Considering potential side } \\
\text { effects of behavior change } \\
\text { in single domains (e.g., } \\
\text { spill-over effects, moral } \\
\text { licensing) }\end{array}$ & $\begin{array}{l}\text { Considering embodied } \\
\text { energy in products and } \\
\text { services }\end{array}$ & $\begin{array}{l}\text { No systematic } \\
\text { approaches to } \\
\text { individual energy } \\
\text { consumption } \\
\text { patterns and its } \\
\text { change in sociology }\end{array}$ & \\
\hline
\end{tabular}

TABLE 2 | Explanantia in the foci of the different disciplines.

\begin{tabular}{|c|c|c|c|c|c|c|}
\hline & Psychology & Economics & Consumer behavior & Business science & Sociology & $\begin{array}{l}\text { Political } \\
\text { science }\end{array}$ \\
\hline $\begin{array}{l}\text { Question (2): } \\
\text { explanantia for } \\
\text { explaining ECB }\end{array}$ & $\begin{array}{l}\text { Belief structures, value } \\
\text { systems, attitudes, } \\
\text { emotions, social norms; } \\
\text { complex interplay } \\
\text { between individual } \\
\text { factors and know-how, } \\
\text { as well as social rules } \\
\text { and norms }\end{array}$ & $\begin{array}{l}\text { Prices and income; } \\
\text { social considerations, } \\
\text { pro-environmental } \\
\text { attitudes, risk aversion; } \\
\text { differences in incentive } \\
\text { structures; unconscious } \\
\text { processes (e.g., } \\
\text { preference learning) }\end{array}$ & $\begin{array}{l}\text { Characteristics of } \\
\text { eco-conscious consumers } \\
\text { (incl. demographic, } \\
\text { psychographic, and } \\
\text { behavioral variables), } \\
\text { heuristics, and related } \\
\text { biases in decision-making }\end{array}$ & $\begin{array}{l}\text { Prices, seasonality, } \\
\text { consumer profile, } \\
\text { consumer past } \\
\text { demand, etc. }\end{array}$ & $\begin{array}{l}\text { Symbolic meanings; } \\
\text { distinction, status } \\
\text { (hierarchies, classes, } \\
\text { milieu); practices, habits, } \\
\text { routines; distribution of } \\
\text { resources; maximization } \\
\text { of utilities }\end{array}$ & $\mathrm{N} / \mathrm{A}$ \\
\hline $\begin{array}{l}\text { Question (4): } \\
\text { explanantia for } \\
\text { explaining change } \\
\text { of ECB }\end{array}$ & $\begin{array}{l}\text { Changed values, norms, } \\
\text { attitudes etc. }\end{array}$ & $\begin{array}{l}\text { Changed prices, } \\
\text { incentive structures; } \\
\text { dealing with and using } \\
\text { decision biases etc. }\end{array}$ & $\begin{array}{l}\text { Changed values, norms, } \\
\text { attitudes, access to } \\
\text { information, pricing, etc. }\end{array}$ & $\begin{array}{l}\text { Market segmentation; } \\
\text { product accessibility/ } \\
\text { availability, pricing, etc. }\end{array}$ & $\begin{array}{l}\text { Changed symbolic } \\
\text { meanings or identities or } \\
\text { routines etc. }\end{array}$ & $\mathrm{N} / \mathrm{A}$ \\
\hline $\begin{array}{l}\text { Desiderata/ } \\
\text { interfaces }\end{array}$ & $\begin{array}{l}\text { Knowing interplay of } \\
\text { psychological, socio- } \\
\text { demographic, and } \\
\text { spatial factors }\end{array}$ & $\begin{array}{l}\text { Understanding } \\
\text { behavioral variation } \\
\text { beyond the variations in } \\
\text { budget and information } \\
\text { constraints }\end{array}$ & $\begin{array}{l}\text { Better understanding } \\
\text { of the effectiveness of } \\
\text { governmental incentives, } \\
\text { social marketing, innovative } \\
\text { financing models, etc. }\end{array}$ & $\begin{array}{l}\text { Understanding how } \\
\text { businesses affect } \\
\text { part of ECB and how } \\
\text { these business factors } \\
\text { interact with others }\end{array}$ & $\begin{array}{l}\text { Intra-individual processes, } \\
\text { effects of governance }\end{array}$ & $\mathrm{N} / \mathrm{A}$ \\
\hline
\end{tabular}


TABLE 3 | Governance in the foci of the different disciplines.

\begin{tabular}{|c|c|c|c|c|c|c|}
\hline & Psychology & Economics & Consumer behavior & Business science & Sociology & Political science \\
\hline $\begin{array}{l}\text { Question (5): } \\
\text { governance of } \\
\text { change of ECB }\end{array}$ & $\begin{array}{l}\text { Tailored interventions, } \\
\text { social feedback; } \\
\text { descriptive and } \\
\text { injunctive norms; social } \\
\text { culture; nudging }\end{array}$ & $\begin{array}{l}\text { Price-based } \\
\text { instruments; } \\
\text { overcoming biases } \\
\text { and using biases }\end{array}$ & $\begin{array}{l}\text { Policy instruments } \\
\text { and social marketing } \\
\text { campaigns }\end{array}$ & $\begin{array}{l}\text { Social marketing strategies } \\
\text { and tactics; product and } \\
\text { service innovations }\end{array}$ & $\begin{array}{l}\text { Interaction between } \\
\text { action of individuals } \\
\text { and social structures, } \\
\text { feedback loops }\end{array}$ & $\begin{array}{l}\text { Multiple policy } \\
\text { instruments with } \\
\text { different steering } \\
\text { potentials }\end{array}$ \\
\hline $\begin{array}{l}\text { Desiderata/ } \\
\text { interfaces }\end{array}$ & $\begin{array}{l}\text { Understanding the } \\
\text { interplay of the factors }\end{array}$ & $\begin{array}{l}\text { Integrating socio- } \\
\text { economic and } \\
\text { psychological } \\
\text { determinants }\end{array}$ & $\begin{array}{l}\text { Understanding the } \\
\text { impact of the different } \\
\text { explanantia on change }\end{array}$ & $\begin{array}{l}\text { Integrating cross- } \\
\text { disciplinary insights into } \\
\text { marketing strategies; } \\
\text { understanding potential for } \\
\text { increasing competitiveness } \\
\text { through change }\end{array}$ & $\begin{array}{l}\text { Linking sociological } \\
\text { approaches } \\
\text { to insights on } \\
\text { explanantia from } \\
\text { e.g., psychology and } \\
\text { economics }\end{array}$ & $\begin{array}{l}\text { Identification of } \\
\text { access points for } \\
\text { political steering; } \\
\text { understanding the } \\
\text { interplay of multiple } \\
\text { factors }\end{array}$ \\
\hline
\end{tabular}

respect social segmentation and lifestyle aspects have an impact on ECB and its change, however, has so far not been systematically addressed (e.g., Barr and Gilg, 2006; Stephenson et al., 2010). Finally, there are not many differences between factors explaining the behavior and the factors for explaining its change on the level of abstraction we are dealing with here. If values are an explaining factor of ECB, then values will also function as an explaining factor in changing the behavior. The difference in behavior will result from a difference in the value set. Following this line, we get the following answers regarding questions (2) and (4).

(5): governance: the last question concerns the constituents to be taken into account in steering change of ECB (Table 3). Such changes are purposely brought about by some steering activities mostly against the backdrop of considering public goods and directed on certain factors in (4). ${ }^{3}$ The spectrum of related candidates given covers the whole range of policy instruments as well as social and market interventions. From an economic perspective, price-based instruments (taxes, subsidies, differentiated rates) and legal regulations are considered to be the most effective policy measures. Psychology as well as sociology points to reflective or competition-like feedback based factors in daily life, business science to new products and services, etc. Collecting again the main elements given above by the disciplines, we gain the following picture regarding question (5).

Obviously, there is again variation regarding, for example, the level of change (individual, organizational, and systemic) but also regarding the scope of governance, for example, covering only the governmental or also the civil society side. In addition, all disciplines point to different loose ends that need to be filled in collaboration with other disciplines.

Against this backdrop, we are tempted to summarize the current state of the art as follows: there is only partial knowledge on what forms of governance induce which changes in what kind of energyrelated behavior of which individuals. One important reason for this situation is that the manifold of factors to be explained - be it consumption or be it change of behavior - or for explaining ECB and its change are only partly linked systematically. An integrated framework could allow doing this in a systematic way.

\footnotetext{
${ }^{3}$ The existing ECB is already an effect of multiple steering efforts within different governance arrangements. Steering change of ECB can also be read as changing governance arrangements.
}

\section{An Integrated Framework}

There are no strict borderlines between models and frameworks and both terms are used in a variety of ways (cf. Frigg and Hartmann, 2012 on models). Here, we refer to the following distinction: while a model tends to be object-specific and explanatory, a conceptual framework provides a rather general descriptive foundation for explanatory inquiries. Accordingly, it does not provide explanations by itself, but frames the space for searching for explanations. Moreover and in contrast to the frameworks presented in Section "Paving the Way Towards an Integrated Framework (Relevance And Gaps)" above, we refrain from building the framework onto a specific theoretical fundament. Searching for such a common theoretical basis is an unrealistic endeavor given the manifold of theoretical behavior approaches, e.g., rational choice, bounded rationality, theory of planned behavior, norm-activation-model, value-belief-norm characteristics, social practice theory etc. (cf. Keirstead, 2006; Wilson and Dowlatabadi, 2007; Darnton, 2008; Stephenson et.al, 2010; Karatasou et al., 2014). Accordingly, the framework is problem oriented, not theory oriented.

In addition, Darnton (2008) draws our attention to some specific challenges. First, a framework should display a reasonable balance between simplification and comprehensibility, i.e., neither abstracting from too many factors that characterize a situated individual, nor trying to include as many factors as possible. Second, the scope of a framework is restricted to what has been framed as belonging to the explanandum (see Section "Problem Statement"). If the explanandum is "environmentally friendly behavior", the according framework could be different in comparison to "ECB." Third, the distinction between explaining behavior and explaining change of behavior has to be captured. Finally, a framework on ECB should include social structuration and not to go along an abstract type of consumer (everyman-models).

We will proceed as follows to serve all the stated requirements: we will frame the explananda (what has to be explained) in a first step, hence approaching question (1) regarding ECB and question (3) regarding its change. The second step concerns the explanantia, taking up questions (2) and (4) on the factors that explain the behavior and its change respectively, by introducing the categories "Opportunity Space" and "Decision-Making" as well as an approach for social segmentation. The third step would then deal with the governance aspects, related to question (5). The thus composed framework is based on the results of the disciplinary reviews. 
However, it also goes beyond them by relating and integrating them within an interdisciplinary framework.

\section{Explananda: Types of ECB and Their Change}

When talking about ECB, it seems to be tempting to envisage the consumed energy, expressed in some $\mathrm{kJ} /$ individual, as the object of analysis. However, no discipline goes along that line. Instead, it has become standard to talk in terms of "energy services." The latter takes into account (1) that individuals generally consume goods and services, i.e., do not use energy directly, but are demanding services like a heating system that (2) serve specific benefits expressing subjective well-being like having it nice and warm. Turning the heating on is connected to coziness and health, using the car is often associated with comfort and convenience etc. (Shove, 2003). The last example adumbrates, however, that the associated underlying expectations regarding well-being could differ remarkably across the individuals.

Bergius suggested distinguishing between action-specific and material-specific ECB (Bergius, 1984). Another option is to distinguish between using and purchasing. We follow Bergius here by integrating the latter into it. Lighting, cooking, driving by car, and watching TV are examples for action-specific ECB accompanied by some energy consumption. In contrast, material-specific ECB are normally purchasing activities that do not include any direct energy consumption. However, there is already a notable amount of energy consumed for production and transportation of the products when looking at the whole life cycle of a product: embodied energy. Embodied or material-specific ECB not only concerns energy-related goods, such as washing machines, light bulbs, or heat pumps, but also all kinds of consumable products, i.e., soft goods as food, apparel, cosmetics, paper products, personal products, as well as hard goods like furniture, sports equipment, toys, etc. By further distinguishing the main consumption domains "heating," "electricity," "mobility," and "consumption of products," we get to the table in Figure 1. The categories within the frame display our answer to the first question. The examples indicate possible exemplifications.

Although material-specific ECB is often "single-shot-behavior," some purchase activities especially in the field of consumption of products can become habits and routines. And although actionspecific ECB is very often dominated by routines, there are cases of single shots in that field as well (e.g., realizing some specific traveling). Hence, a specific behavior is either single-shot or habit/ routine. In addition, the relation to "well-being"/quality of life is included by definition in "demand of energy services." But taking into account that it is a non-observable part of the behavior, it is not explicitly specified in Figure 1.

There seems to be a straightforward answer for question (3) on "what is change of ECB": the amount of reduced energy like some $\Delta \mathrm{kJ} /$ individual or some $\Delta \mathrm{TJ}$ on an aggregated level. Following our line of reasoning, however, this can hardly be the explanandum because individuals do not consume energy but energy services. "Change of ECB" means changed demand for energy services. The explanandum could therefore encompass any feature within Figure 1 including changed expectations toward "demands" and thus quality of life. Notwithstanding the envisaged reduction goals, the general components from question (1) remain the same. It is still ECB we are looking at. Two additional components need to be included to cope with the fact that we are talking about change: the time factor and the societal goal in question. Accordingly, our second explanandum (a) consists in the same categories as in Figure 1, including (b) a time factor, and (c) variations in demand of energy services that are expected to contribute to achieving the reduction goal.

Reducing energy consumption means in general changed demand of energy services or products either on the action

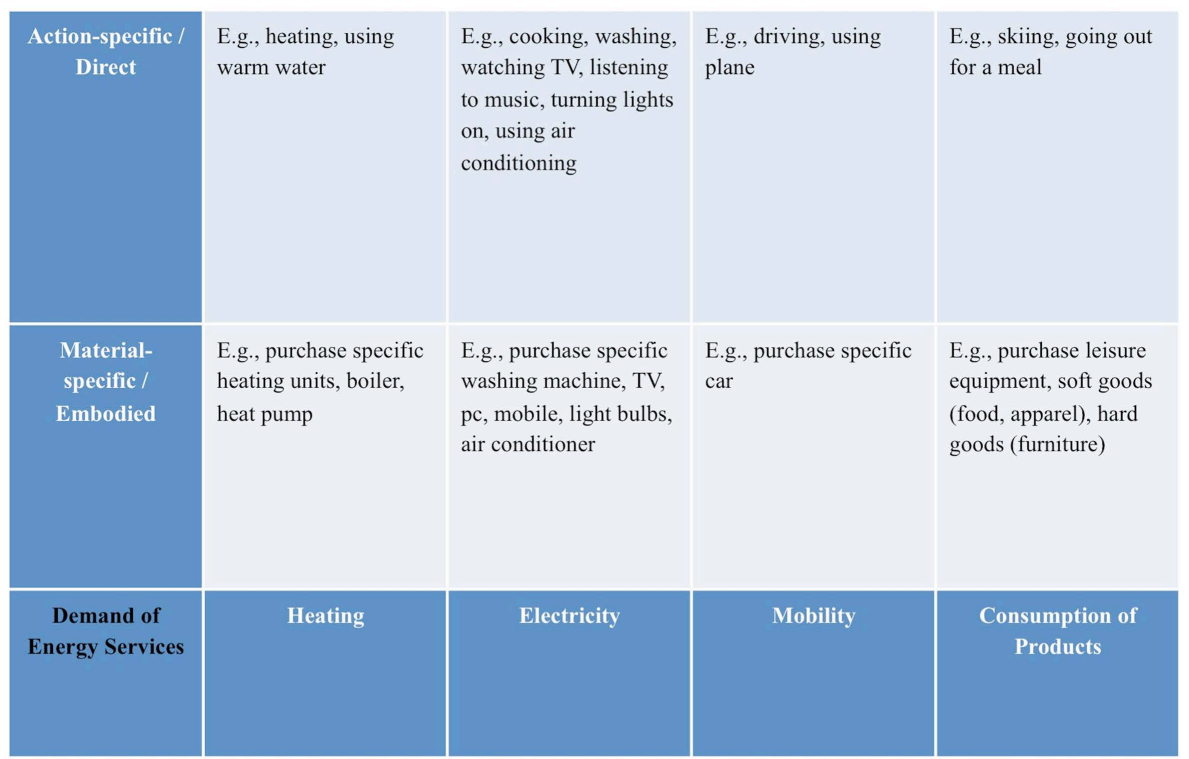

FIGURE 1 | Explananda - examples for types of ECB. 
or the material-related side. Material-related improvements cover, for example, increased efficiency in terms of replacement of existing appliances, goods, and services by more energy-efficient ones (e.g., purchase a new A+++-rated refrigerator or a fuel-saving car). Action-related improvements primarily comprise changes in the use of energy services, e.g., the renouncement of some energy consuming activities or its substitution by the use of less energy-intensive services (in the sense of sufficiency strategies). For example, individuals can alter their heating and ventilation habits, can renounce using specific appliances, can cycle instead of drive, and can consume less energy-intensive products, e.g., eat less meat. Moreover, there are two rather new phenomena. Materialrelated improvements could also comprise "prosumer" activities: energy consumption reduction in terms of self-generation of energy or products. Moreover, there is "outsourcing" the consumption, especially by substitution of personal property and use of shared services instead. Figure 2 indicates a number of options leading to changed demand, even though disentangling action- and material- specific behavior is not always straightforward especially in the field of products.

The domain of "changes" then also includes changed expectations regarding quality of life. Research has shown that people in the developed world like Japan, the U.S., or Europe have not become happier despite a massive increase in wealth (and directly related increase in energy use/ $\mathrm{CO}_{2}$ emissions) (Easterlin, 1995; Binswanger, 2006; Easterlin et al., 2010; Easterlin, 1974). Notwithstanding, there is also some evidence that income losses can have dramatic negative impacts on wellbeing (Boyce et al., 2013). Howsoever, the relation between energy services and well-being makes up an important field for research on change of ECB.

To sum up, we propose to frame the explananda - the individual consumption behavior and its change, respectively, as illustrated in Figure 3.

\section{Explanantia: Explaining Energy Consumption Behavior and its Change}

As we have seen in Section "Paving the Way Towards an integrated framework (Relevance And Gaps)," the disciplines offer a variety of determinants for explaining the behavior in question: psychology points to values, attitudes, emotions, while economics refer to socio-economic determinants such as income and prices, consumer behavior and economics to decision heuristics, and sociology to determinants like milieu, status, and inequalities. All disciplines contributing to explaining ECB stress the interplay between the different factors, and consumer behavior research is already an interdisciplinary endeavor (cf. Section "ECB and its Change from a Consumer Behavior Perspective"). The challenge for answering question (2) is not so much related to the factors themselves, as it is related to organizing them by taking account of explicitly not basing it on a specific theory (cf. above).

What we suggest here, is to organize the determinants against the weak background assumption that the consumer is an actor (agent). That assumption is weak in so far as we do not invest a specific actor theory. Nevertheless, the assumption is not "content-neutral," because there are some general features related to "being an agent." These features are in turn related to the rationale motivating our suggestion. There are always (either explicitly or implicitly hidden in routines) choices to be made (decision making) and there are always pre-conditions when talking about choices (the related opportunity space). The observable behavior (the above addressed explananda) results from explicit choices or routines on the basis of an existing opportunity space.

Against this backdrop, we suggest framing the realm of explanantia as follows: to capture the interplay between "the social" and the "individual" factors consistently pointed out by the disciplines (cf. Section "First Synthesis: Categories, Gaps and Challenges"), we use the term "situated individual" to highlight that we are looking at individuals living embedded in complex

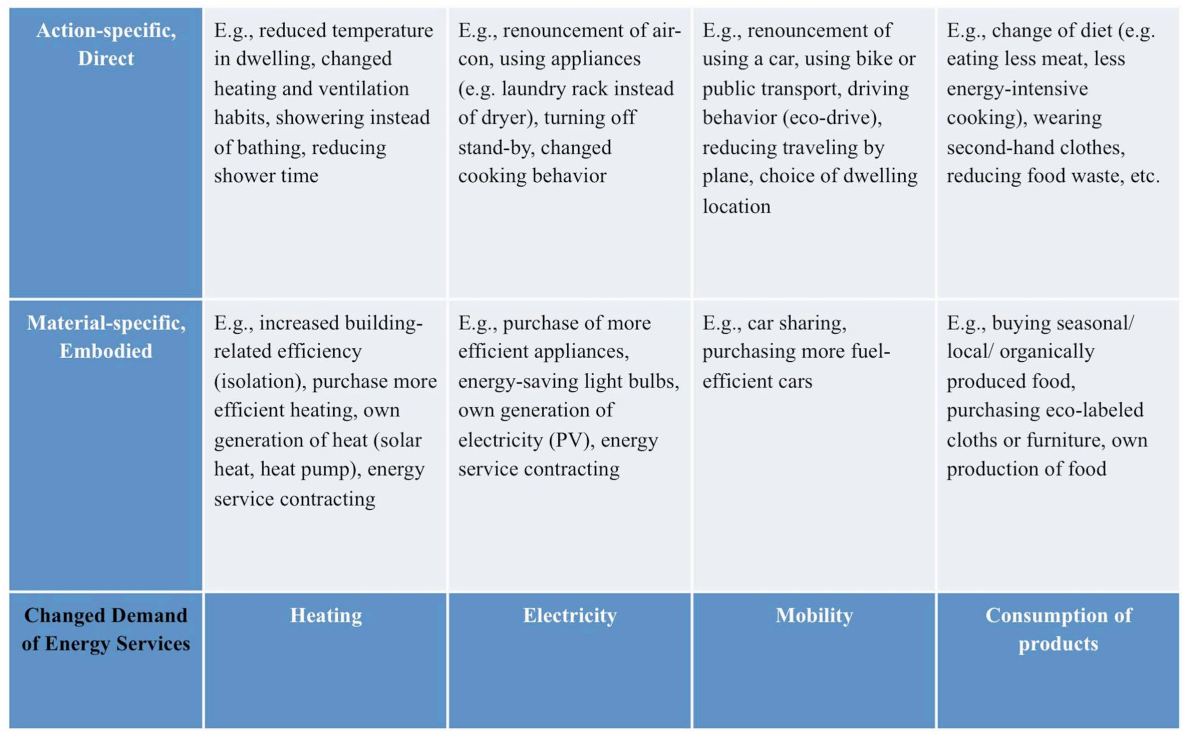

FIGURE 2 | Explananda - examples for types of changed ECB 


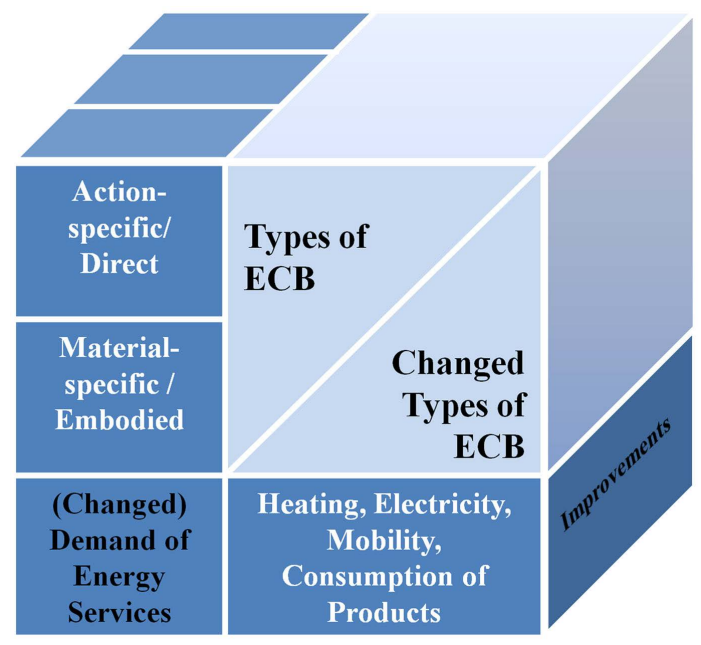

FIGURE 3 | Explananda - types and changed types of ECB

social environments. The explicit choices or the routines leading to ECB of such a situated individual are then thought to be based on two major categories: the existing opportunity space and the individual's decision making.

\section{Opportunity Space}

There are two types of factors that make up an individual's opportunity space: factors on the macro-level expressing the social environment, and factors on the individual level. A distinguishing feature between them is that the former are normally not directly influenced by the individual, whereas the latter could be. An individual cannot change, e.g., the technological options as an individual, but she can try to change her educational or economic performance.

We label the structural elements framing the action fields for individuals on the macro level as belonging to the social opportunity space (SOS). SOS is thought to encompass factors such as [cf. Sections "ECB and its Change from a Psychological Perspective," "ECB and its Change from an Economic Perspective," "ECB and its Change from a Consumer Behavior Perspective," "ECB and its Change from a Business Science Perspective," "ECB and its Change from a Sociological Perspective," and "Governance of ECB from a Political Science Perspective"]): commercially available technologies or facilities, the economy in form of market structure, prices, the demography, existing institutions as norms, policies, and organizations, and culture (symbolic meanings). For example, if certain (energy-efficient) technologies are not commercially available, the options for changing the material-specific consumption behavior are restricted accordingly. Likewise, if there are legal norms constraining energy consumption, e.g., isolation norms for dwellings, the individual's behavior is shaped by such a norm. One might add geography and climate to include spatial factors (e.g., regarding settlements).

Contrarily, we name the many factors on the micro-level discussed by the disciplines above as belonging to the "individual opportunity space" (IOS): age, gender, and constitutional factors, material living conditions (housing, appliances, education, income, and workplace), support networks, (family and friends), lifestyle factors according to the milieu etc. Hence, all determining factors depicted by the disciplines can be either subsumed to SOS or IOS to the exception of those belonging to mental decision processes.

The relation between SOS and IOS is thought to be twofold. On the one hand, the components of the SOS are to some extent translated by the individuals into their IOS to form their behavior. For example, selected from the commercially available technologies there is a certain stock of available appliances in the households. On the other hand, there are feedback-loops from IOS to SOS. Changed demand on the individual level through change of expectations can induce changes on the SOS level, e.g., new products and services or change of market conditions.

The SOS and IOS encompass together the realm of potential determinants of ECB as well as its change. If these factors make up ECB, then they will also make up its change as we already argued above. It is not the factor per se that will change, but how it is instantiated today. Prices will always be determinants, but their variation leads to different behaviors. The task consists in looking at those variations that will lead to the expected change of behavior. Moreover and as expressed by the notion "opportunity," it is neither the case that every single contextual factor is a necessary prerequisite in explaining the observable ECB nor is the listing of the factors in the graph meant as being exhaustive.

\section{Decision-Making}

Given their social and IOS, individuals make specific decisions "translating" the elements within the OS into a specific observable material- or action-specific ECB. Hence, besides the factors within the OS, there are additionally those factors that are determinants for "decision-making." As described in Sections "ECB and its Change from a Psychological Perspective" and "ECB and its Change from Consumer Behavior Perspective" above, these are belief structures, value systems, attitudes, emotions, motivations, heuristics, and biases. For example, demands for comfort, motivations like financial benefits, or environmentally friendly values and emotions could translate the OS-factors into behavior X, whereas other determinants for decision-making could lead to behavior Y. Thereby, we let "decision-making" encompass both - conscious choices as well as routines, as long as the latter implicitly includes the option for choices. Together with SOS and IOS, this leads us to Figure 4 as the overall scheme for explanantia (where choices and routines are of course not themselves explanantia but placeholders for linking the explanantia to the explanandum).

That scheme of explanantia is meant to function as a heuristic help sort the complexity of potential explaining factors. It is not to be confused with a sequenced model or theory, as we already pointed out above. No causal claims have been linked to the factors within SOS and IOS and the factors for decision-making. Causal claims have to be empirically established. We expect that the according evidence on how the different factors in and between the three different dimensions (SOS, IOS, and DM) "play" together will lead to a better understanding of what determines ECB and its change. For example, constraints in the SOS might be so severe as to make it extremely costly for an individual to act on his/her values 


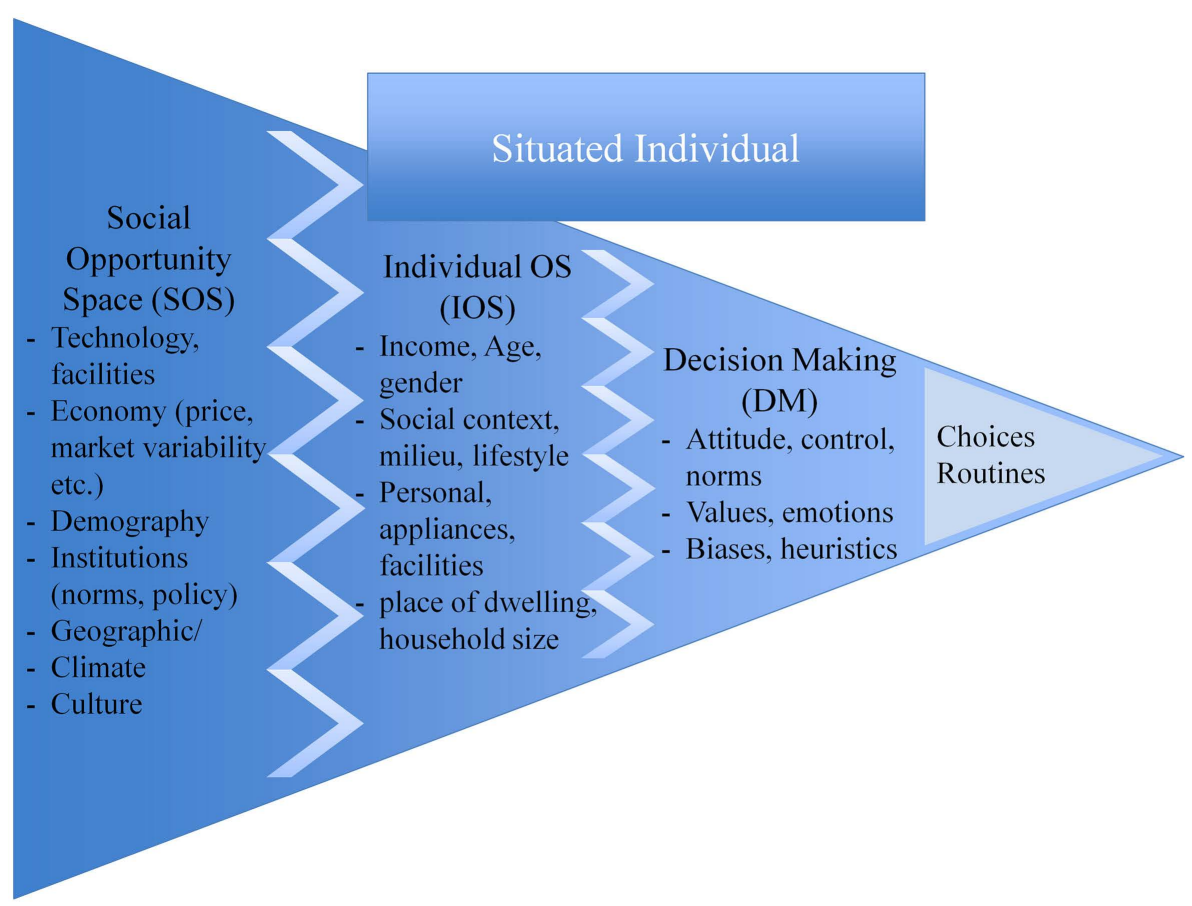

FIGURE 4 | Explanantia - determinants of ECB and its change.

or to react to price incentives. Similarly, the individuals' value system might determine how they react to common behavioral economic incentives. For example, in the U.S., conservatives have been found to be substantially less responsive to environmental nudges than liberals (Costa and Kahn, 2013). A similar effect might explain why individuals react so differently to the very same economic incentive to invest in home improvements (Stern, 1986, 2014). Thus, by starting to look into how these different dimensions interact, we expect to get a more comprehensive explanation of ECB and its changes. Finally, the relevance and impact of social segmentations need to be scrutinized.

\section{Segmentation of Individuals}

Social segmentation of individuals and the related lifestyles are an important field of research especially emphasized above by several disciplines, including business science and consumer behavior (market segmentations) and sociology (social structuration, milieus). Darnton (2008) also emphasized that analyzing ECB should include social structuration and not go along an abstract type of consumer (everyman-models). Although, there is so far only a small amount of studies in the field of ECB using social segmentation as an additional explanatory category, those who go along it reveal interesting insights (e.g., Spaargaren, 2003; Barr and Gilg, 2006; Jetzkowitz et al., 2007; Sütterlin et al., 2011). The argument given in favor of including social segmentation as an analytical category often consists in claiming that individuals from different socially segmented groups have different sensitivities toward steering instruments, products, and services. Knowing the ECB within different social segments would, as the argument goes, improve the capacity for steering. It would allow providing tailor-made instruments or services.
We leave it an open question here, whether social segmentation is an additional explanatory category to our scheme or whether social segmentations basically represent clusters based on combinations of the different factors set up by our scheme. There is not enough space here to enter the according debate on methods and approaches that capture social segmentation (e.g., inductive on specific domains or deductive on the society as a whole), and it is fairly doubtful whether this can be done without further theoretical investments. Given the assumed importance of social segmentation and related lifestyles, however, it should be explicitly taken account of when addressing ECB and its change.

\section{Governance of Individual Behavior Patterns}

The third component of our framework deals with the governance of individual behavior, following question (5). "Governance" is not just another word for "policy" but refers to constellations of instruments, institutions, and actors that collectively shape individual action toward common goals (cf. Section "Governance of ECB from a Political Science Perspective"). "Governance of ECB" potentially includes all three dimensions politics, polity, and policy (cf. Section "Governance of ECB from a Political Science Perspective"). Drawing on this and in light of the differentiated picture of ECB as well as the multiple factors that explain the various types of behavior and their changes, governance of ECB turns out to be a complex issue itself. It is not merely about the proper design of single policy instruments addressing particular factors. Rather, governance is about the design of complex instrumental arrangements that address different factors in a coordinated way. These instrumental arrangements are themselves created and enacted by institutionally embedded collective actors (i.e., not only the state but also business 
and civil society) affecting the design and implementation of instruments as well as their legitimacy and effectiveness. Questions to be answered then include: who (what constellation of actors) is governing, under which conditions (institutional setting) with what means (set of policy instruments) to address which determining factors of which type of individual energy-related behavior? These basic questions can orient both the empirical analysis of existing governance arrangements and the design of practical governance arrangements. In Figure 5 accordingly, the three domains policy, politics, and polity frame the triangle, taking account of policies, procedural factors such as networks, hierarchies, resources, and structural factors like institutional settings. The arrows above the triangle link the governance scheme to the scheme of determinants (SOS, IOS, and decision making).

The general three-dimensional conception of governance can be further specified by including the characteristics (a) group-specific; (b) multi-factorial; (c) integrated; and (d) adaptive:

(a) group-specificity: governance of ECB can address diverse groups of individuals: different individuals with different behavior patterns, not acting constantly rational or consistent. Moreover, there are different types of ECB. By analyzing or designing governance of ECB, the potential relevance of group-specific factors or the characteristics of different ECBtypes need to be considered.

(b) multi-factorial: governance interventions can be directed to different components of the opportunity space or decisionmaking (access points). For example, one could try modifying market conditions or legal norms (arrow to the SOS) or to directly influence the ECB by a change of price structures (arrow to the IOS). Likewise, factors such as heuristics behind

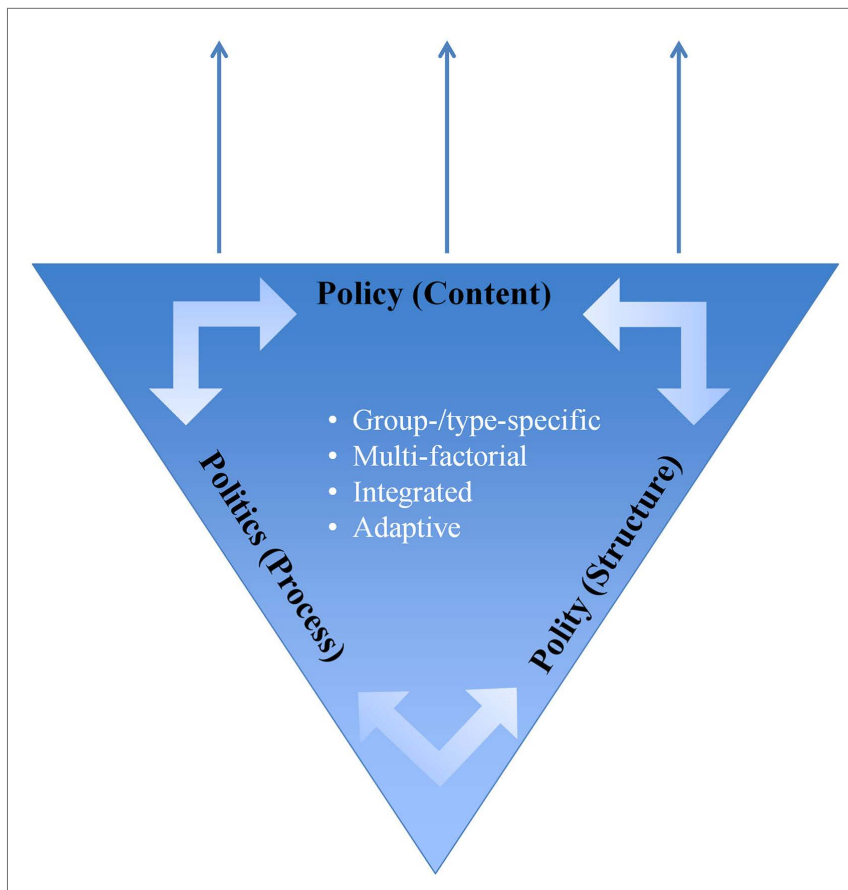

FIGURE 5 | Governance of changing ECB decisions or routines could be addressed, say by interventions like nudges, or information campaigns. Thus, interventions can trigger a number of factors. However, not all factors that explain ECB and its change are potential access points for governance, e.g., demography, geography, age, or gender.

(c) integrated: additionally and related to (b), there are multiinstrumental settings (policy mixes), accompanied by interactions between the different instruments. The according analysis (or design) of policy instruments on change of behavior then should not only address sets but also combinations of instruments and their coordination by taking their aggregated effects into account.

(d) adaptive: current patterns of ECB are the result of a certain incumbent governance regime and changing ECB requires its transformation. As individual behavior can only be changed step by step and as attempts of governing energy-related behavior are embedded in complex societal situations that include many options for unexpected development and side effects, governance of change is like an ongoing task. Analytically, it requires including uncertainty and the capacities for on-going adaptive forms of governance.

Put in a nutshell, "governance" offers a differentiated set of categories for analyzing the steering side of change of ECB. It directs the researcher to taking account of the different dimensions of governance, of different groups and types of behavior as well as the variety of explaining factors, and requirements of integration and adaptability. It provides a conceptual basis, which allows looking at which type of governance arrangements has the potential to influence which type of determinants to get which type of change of behavior. Which factors are really relevant in what fields of change of ECB has to be established empirically.

Besides, the question of desirability or legitimacy arises. The "bossy state" telling citizens how to behave or how to change behavior and leaving the individual with only restricted choices is rarely compatible with a liberal stand. Likewise, scientists can certainly not prescribe how individuals should live their lives. Is there something like a liberal paternalism expressed for example in nudging efforts? In any case, research on governance of change of behavior needs to be accompanied by scrutinizing the legitimacy of such governance.

Putting the three pieces together then, we come to the overall framework as illustrated in Figure 6.

\section{Synthesis and Outlook}

The framework displays our answers to the five initially stated questions and links the three analytical aspects (explananda, explanantia, and governance). It systematically distinguishes the two explanatory perspectives and offers an integrated approach to understand and explain ECB and its (governed) change. Based on the best available disciplinary and interdisciplinary knowledge and aggregated over the different subsectors of consumption, our framework provides an interdisciplinary basis for linking different aspects in empirical settings. The framework - not model or theory - does not offer explanations or evidence about sequenced relations. Moreover, we certainly do not claim that an empirical research design has to pay attention to all elements addressed by the framework. The framework 


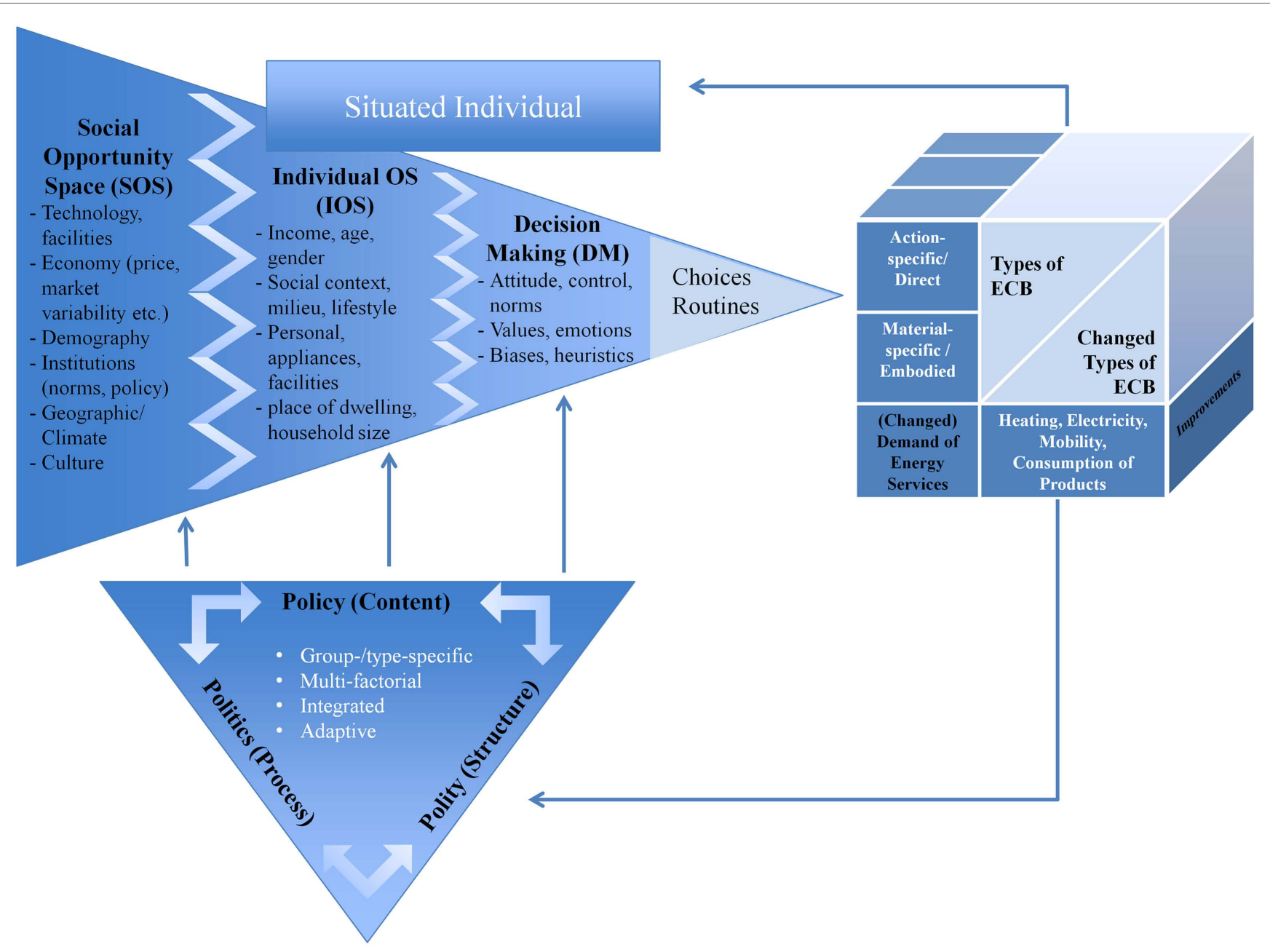

FIGURE 6 | Integrated framework - understanding ECB and the governance of its change.

is a heuristic tool to guide further theoretical work and empirical analyses by especially addressing possible interfaces between the manifold of factors. Particularly, we expect our framework to guide the research in our interdisciplinary research consortium within SCCER-CREST's, leading to concrete recommendations on governance of individual energy-related consumption behavior.

\section{References}

Abrahamse, W., and Steg, L. (2009). How do socio-demographic and psychological factors relate to households' direct and indirect energy use and savings? J. Econ. Psychol. 30, 711-720. doi:10.1016/j.joep.2009.05.006

Abrahamse, W., Steg, L., Vlek, C., and Rothengatter, T. (2005). A review of intervention studies aimed at household energy conservation. J. Environ. Psychol. 25, 273-291. doi:10.1016/j.jenvp.2005.08.002

Ajzen, I. (1991). The theory of planned behavior. Organ. Behav. Hum. Decis. Process 50, 179-211. doi:10.1016/0749-5978(91)90020-T

Allen, C. T., Calantone, R. J., and Schewe, C. D. (1982). Consumers' attitudes about energy conservation in Sweden, Canada, and the United States, with implications for policymakers. J. Mark. Public Policy 1, 57-67. doi: $10.2307 / 30000007$

\section{Acknowledgments}

This research is part of the activities of SCCER CREST (Swiss Competence Center for Energy Research), which is financially supported by the Swiss Commission for Technology and Innovation (CTI) under Grant No. 466 KTI.2014.0114.

Aronson, E., and O'Leary, M. (1982). The relative effectiveness of models and prompts on energy conservation: a field experiment in a shower room. J. Environ. Syst. 12, 219-224. doi:10.2190/UBD5-4Y9B-61EF-WUM6

Auh, S., Bell, S. J., McLeod, C. S., and Shih, E. (2007). Co-production and customer loyalty in financial services. J. Retailing 83, 359-370. doi:10.1016/j.jretai.2007.03.001

Ayres, I., Raseman, S., and Shih, A. (2013). Evidence from two large field experiments that peer comparison feedback can reduce residential energy usage. J. Law Econ. Organ. 29, 992-1022. doi:10.1093/jleo/ews020

Baca-Motes, K., Brown, A., Gneezy, A., Keenan, E. A., and Nelson, L. D. (2013). Commitment and behavior change: evidence from the field. J. Consum. Res. 39, 1070-1084. doi:10.1086/667226

Bamberg, S., Ajzen, I., and Schmidt, P. (2003). Choice of travel mode in the theory of planned behavior: the roles of past behavior, habit, and reasoned action. Basic Appl. Soc. Psych. 25, 175-187. doi:10.1207/S15324834BASP2503_01 
Bardach, E. (1979). The Implementation Game. What Happens After a Bill Becomes a Law. Cambridge, MA: MIT Press.

Bardhi, F., and Eckhardt, G. M. (2012). Access-based consumption: the case of car sharing. J. Consum. Res. 39, 881-898. doi:10.1086/666376

Barr, S., and Gilg, A. (2006). Sustainable lifestyles: framing environmental action in and around the home. Geoforum 37, 906-920. doi:10.1016/j.geoforum.2006.05.002

Bauman, Z. (2001). Consuming Life. J. Consum. Cult. 1, 9-29. doi:10.1177/146954050100100102

Baydoun, M. (2013). Using innovation research to achieve sustainability in urban developments: the case of Masdar. Int. J. Technol. Manag. Sustain. Dev. 12, 3-14. doi:10.1386/tmsd.12.1.3_1

Belk, R. (2010). Sharing. J. Consum. Res. 36, 715-734. doi:10.1086/612649

Bemelmans-Videc, M., Rist, R., and Vedung, E. (eds) (2011). Carrots, Sticks, and Sermons: Policy Instruments and Their Evaluation, Vol. 1. New Brunswick, NJ: Transaction Publishers.

Bergius, R. (1984). Sozialwissenschaftliche Forschungen zum Energieproblem der Wirtschaft. Psychol. Rundsch. 4, 185-197.

BFE. (2014). Überblick über den Energieverbrauch der Schweiz im Jahr 2013. Bern: BFE.

BFE. (2013). Analyse des schweizerischen Energieverbrauchs 2000-2012 nach Verwendungszwecken. Authors: Prognos, Infras, TEP Energy. Bern: BFE.

Binswanger, M. (2006). Why does income growth fail to make us happier? Searching for the treadmills behind the paradox of happiness. J. Socio Econ. 35, 366-381. doi:10.1016/j.socec.2005.11.040

Botsman, R., and Rogers, R. (2010). Beyond zipcar: collaborative consumption. Harv. Bus. Rev. 88, 30.

Bourdieu, P. (1979). La Distinction. Critique Sociale Du Jugement. Paris: Les éditions de minuit.

Boyce, C. J., Wood, A. M., Banks, J., Clark, A. E., and Brown, G. D. (2013). Money, well-being, and loss aversion. does an income loss have a greater effect on well-being than an equivalent income gain? Psychol. Sci. 24, 2557-2562. doi:10.1177/0956797613496436

Brabec, M., Konár, O., Pelikán, E., and Malý, M. (2008). A nonlinear mixed effects model for the prediction of natural gas consumption by individual customers. Int. J. Forecast. 24, 659-678. doi:10.1016/j.ijforecast.2008.08.005

Brennan, T. J. (2007). Consumer preference not to choose: methodological and policy implications. Energy Policy 35, 1616-1627. doi:10.1016/j.enpol.2006.04.023

Breukers, S., Mourik, R., and Heiskanen, E. (2013). “Changing energy demand behavior: potential of demand-side-management," in Handbook of Sustainable Engineering, eds J. Kauffmann and K.-M. Lee (Dordrecht: Springer), 773-792.

Brosch, T., Patel, M. K., and Sander, D. (2014). Affective influences on energyrelated decisions and behaviors. Front. Energy Res. 2:11. doi:10.3389/fenrg.2014.00011

Brosch, T., and Sander, D. (2013). Neurocognitive mechanisms underlying value-based decision-making: from core values to economic value. Front. Hum. Neurosci. 7:398. doi:10.3389/fnhum.2013.00398

Burchell, K., Rettie, R., and Patel, K. (2013). Marketing social norms: social marketing and the 'social norm approach'. J. Consum. Behav. 12, 1-9. doi:10.1002/cb.1395

Burroughs, J. E., and Rindfleisch, A. (2002). Materialism and well-being: a conflicting values perspective. J. Consum. Res. 29, 348-370. doi:10.1086/344429

Cainelli, G., and Mazzanti, M. (2013). Environmental innovations in services: manufacturing - services integration and policy transmissions. Res. Policy 42, 1595-1604. doi:10.1016/j.respol.2013.05.010

Carley, S. (2011). The era of state energy policy innovation: a review of policy instruments. Rev. Policy Res. 28, 265-294. doi:10.1111/j.1541-1338.2011.00495.x

Charlton, N., and Singleton, C. (2014). A refined parametric model for short term load forecasting. Int. J. Forecast. 30, 364-368. doi:10.1016/j.ijforecast.2013.07.003

Coleman, J. S. (1986). Social theory, social research, and a theory of action. Am. J. Sociol. 91, 1309-1335. doi:10.1086/228423

Costa, D. L., and Kahn, M. E. (2013). Energy conservation "Nudges" and environmentalist ideology: evidence from a randomized residential electricity field experiment. J. Eur. Econ. Assoc. 11, 680-702. doi:10.1111/jeea.12011

Darby, S. (2007). "Enough is as good as a feast-sufficiency as policy," in Proceedings, European Council for an Energy-Efficient Economy, La Colle sur Loup.

Darnton, A. (2008). Reference Report: An Overview of Behaviour Change Models and Their Uses: Government Social Research Behaviour Change Knowledge Review, London.

Davis, L. W. (2012). Evaluating the Slow Adoption of Energy Efficient Investments: Are Renters Less Likely to Have Energy Efficient Appliances? In The Design and
Implementation of U.S. Climate Policy, eds D. Fullerton and C. Wolfram (Chicago: University of Chicago Press.), 301-316.

DECC. (2012). The Energy Efficiency Strategy. The Energy Efficiency Opportunity in the UK. London: Crown.

Delmas, M. A., and Montes-Sancho, M. J. (2011). U.S. state policies for renewable energy: context and effectiveness. Energy Policy 39, 2273-2288. doi:10.1016/j. enpol.2011.01.034

Deutsch, M. (2010). Life cycle cost disclosure, consumer behavior, and business implications: evidence from an online field experiment. J. Ind. Ecol. 14, 103-120. doi:10.1111/j.1530-9290.2009.00201.x

Dholakia, R. R., Dholakia, N., and Firat, A. F. (1983). From social psychology to political economy: a model of energy use behavior. J. Econ. Psychol. 3, 231-247. doi:10.1016/0167-4870(83)90004-1

Do Paço, A., and Raposo, M. (2009). "Green" segmentation: an application to the Portuguese consumer market. Mark. Intell. Plann. 27, 364-379. doi:10.1108/02634500910955245

Downs, P. E., and Freiden, J. B. (1983). Investigating potential market segments for energy conservation strategies. J. Public Policy Mark. 2, 136-152.

Durham, C. A., Colby, B. G., and Longstreth, M. (1988). The impact of state tax credits and energy prices on adoption of solar energy systems. Land Econ. 64, 347-355. doi: $10.2307 / 3146307$

Easterlin, R. A. (1974). "Does economic growth improve the human lot? Some empirical evidence," in Nations and Households in Economic Growth: Essays in Honor of Moses Abramovitz, eds R. David and R. Reder (New York, NY: Academic Press), 89-125.

Easterlin, R. A. (1995). Will raising the incomes of all increase the happiness of all? J. Econ. Behav. Organ. 27, 35-47. doi:10.1016/0167-2681(95)00003-B

Easterlin, R. A., McVey, L. A., Switek, M., Sawangfa, O., and Zweig, J. S. (2010). The happiness - income paradox revisited. Proc. Natl. Acad. Sci. U.S.A. 107, 22463-22468. doi:10.1073/pnas.1015962107

Eliadis, P., Hill, M. M., and Howlett, M. (2005). Designing Government: From Instruments to Governance. Montreal/Kingston: McGill-Queen's Press-MQUP.

Favi, C., Germani, M., Marconi, M., and Mengoni, M. (2014). An integrated approach and IT platform to optimise electric motor engineering and design. Int. J. Inform. Technol. Manag. 13, 134-153. doi:10.1504/IJITM.2014.060306

Fischer, M., and Lotz, S. (2014). "Is soft paternalism ethically legitimate? - The relevance of psychological processes for the assessment of nudge-based policies," in CGS Working Papers, 05-02. Cologne: Cologne Graduate School in Management, Economics and Social Sciences.

Foley, H. C., Freihaut, J., Hallacher, P., and Knapp, C. (2011). The greater Philadelphia innovation cluster for energy-efficient buildings: a new model for public-private partnerships. Res. Technol. Manag. 54, 42-48. doi:10.5437/08956308X5406014

Frigg, R., and Hartmann, S. (2012). "Models in science," in The Stanford Encyclopedia of Philosophy, Fall 2012 Edn, ed. E. N. Zalta. Available at: http://plato.stanford.edu/ archives/fall2012/entries/models-science/

Giddens, A. (1991). The Consequences of Modernity. Cambridge: Polity Press.

Gillingham, K., Harding, M., and Rapson, D. (2012). Split incentives in household energy consumption. Energy J. 33, 37-62. doi:10.5547/01956574.33.2.3

Gillingham, K., Newell, R. G., and Palmer, K. (2009). Energy efficiency economics and policy. Annual Review of Resource Economics 1, 597-620. doi:10.1146/annurev. resource.102308.124234

Gillingham, K., and Palmer, K. (2014). Bridging the energy efficiency gap: policy insights from economic theory and empirical evidence. Rev. Environ. Econ. Policy 8, 18-38. doi:10.1093/reep/ret021

Goetzke, F., and Rave, T. (2011). Bicycle use in Germany: explaining differences between municipalities with social network effects. Urban Stud. 48, 427-437. doi:10.1177/0042098009360681

Goldstein, N. J., Cialdini, R. B., and Griskevicius, V. (2008). A room with a viewpoint: using social norms to motivate environmental conservation in hotels. J. Consum. Res. 35, 472-482. doi:10.1086/586910

Greening, A. L., Greene, D. L., and Difiglio, C. (2000). Energy efficiency and consumption-the rebound effect-a survey. Energy Policy 28, 389-401. doi:10.1016/ S0301-4215(00)00021-5

Guagnano, G. A., Stern, P. C., and Dietz, T. (1995). Influences on attitude-behavior relationships - a natural experiment with curbside recycling. Environ. Behav. 27, 699-718. doi:10.1177/0013916595275005

Gyberg, P., and Palm, J. (2009). Influencing households' energy behaviour - how is this done and on what premises? Energy Policy 37, 2807-2813. doi:10.1016/j. enpol.2009.03.043 
Haben, S., Ward, J., Vukadinovic Greetham, D., Singleton, C., and Grindrod, P. (2014). A new error measure for forecasts of household-level, high resolution electrical energy consumption. Int. J. Forecast. 30, 246-256. doi:10.1016/j. ijforecast.2013.08.002

Harland, P., Staats, H., and Wilke, H. A. M. (1999). Explaining proenvironmental intention and behavior by personal norms and the theory of planned behavior. J. Appl. Soc. Psychol. 29, 2505-2528. doi:10.1111/j.1559-1816.1999.tb00123.x

Harvey, M., and Kerin, R. (1977). Perspectives on demarketing during the energy crisis. J. Acad. Mark. Sci. 5, 327-338. doi:10.1007/BF02722063

Heinzle, S. L. (2012). Disclosure of energy operating cost information: a silver bullet for overcoming the energy-efficiency gap? J. Consum. Policy 35, 43-64. doi:10.1007/ s10603-012-9189-6

Heinzle, S. L., and Wüstenhagen, R. (2012). Dynamic adjustment of eco-labeling schemes and consumer choice - the revision of the EU energy label as a missed opportunity? Bus. Strategy Environ. 21, 60-70. doi:10.1002/bse.722

Herring, H., and Roy, R. (2007). Technological innovation, energy efficient design and the rebound effect. Technovation 27, 194-203. doi:10.1016/j.technovation.2006.11.004

Hill, M., and Hupe, P. (2002). Implementing Public Policy: Governance in Theory and in Practice. London: Sage Publications.

Hirst, E. (1980). Review of data related to energy use in residential and commercial buildings. Manage. Sci. 26, 857-870. doi:10.1287/mnsc.26.9.857

Hitchcock, G. (1993). An integrated framework for energy use and behaviour in the domestic sector. Energy Build. 20, 151-157. doi:10.1016/0378-7788(93)90006-G

Hood, C. (1983). The Tools of Government. London: Macmillan.

Howlett, M. (1991). Policy instruments, policy styles, and policy implementation: national approaches to theories of instrument choice. Policy Stud. J. 19, 1-21. doi:10.1111/j.1541-0072.1991.tb01878.x

Howlett, M. (2009). Governance modes, policy regimes and operational plans: a multi-level nested model of policy instrument choice and policy design. Policy Sci. 42, 73-89. doi:10.1007/s11077-009-9079-1

Howlett, M. (2011). Designing public policies: Principles and instruments. London: Routledge.

Jackson, T. (2005). Live better by consuming less? is there a "double dividend" in sustainable consumption? J. Ind. Ecol. 9, 19-36. doi:10.1162/1088198054084734

Jacobson, G. D., Kotchen, M. J., and Vandenbergh, M. P. (2012). The behavioral response to voluntary provision of an environmental public good: evidence from residential electricity demand. Eur. Econ. Rev. 56, 946-960. doi:10.1016/j. euroecorev.2012.02.008

Jaffe, A. B., and Stavins, R. N. (1994). The energy-efficiency gap. What does it mean? Energy Policy 22, 804-810. doi:10.1016/0301-4215(94)90138-4

Jetzkowitz, J., Schneider, J., and Brunzel, S. (2007). Suburbanisation, mobility and the good life in the country': a lifestyle approach to the sociology of Urban sprawl in Germany. Sociol. Ruralis 47, 148-171. doi:10.1111/j.1467-9523.2007.00431.x

Jones, R., Pykett, J., and Whitehead, M. (2014). Changing Behaviours. On the Rise of the Psychological State. Cheltenham: Edward Elgar Publishing.

Jonsson, D. K., Gustafsson, S., Wangel, J., Höjer, M., Lundqvist, P., and Svane, Ö (2011). Energy at your service: highlighting energy usage systems in the context of energy efficiency analysis. Energy Effic. 4, 355-369. doi:10.1007/s12053-010-9103-5

Kaenzig, J., and Wüstenhagen, R. (2010). The effect of life cycle cost information on consumer investment decisions regarding eco-innovation. J. Ind. Ecol. 14, 121-136. doi:10.1111/j.1530-9290.2009.00195.x

Kahneman, D. (2003). A perspective on judgment and choice: mapping bounded rationality. Am. Psychol. 58, 697. doi:10.1037/0003-066X.58.9.697

Karatasou, S., Laskari, M., and Santamouris, M. (2014). Models of behavior change and residential energy use: a review of research directions and findings for behavior-based energy efficiency. Adv. Build. Energy Res. 8(2), 137-147. doi:10.1080/17512549.2013.809275

Keirstead, J. (2006). Evaluating the applicability of integrated domestic energy consumption frameworks in the UK. Energy Policy 34, 3065-3077. doi:10.1016/j. enpol.2005.06.004

Kellett, J. (2007). Community-based energy policy: a practical approach to carbon reduction. J. Environ. Plann. Manag. 50, 381-396. doi:10.1080/09640560701261679

Khazzoom, J. D. (1987). The demand for insulation-a study in the household demand for conservation. Energy J. 8, 73-92.

Kotchen, M., and Moore, M. (2008). Conservation: from voluntary restraint to a voluntary price premium. Environ. Resour. Econ. 40, 195-215. doi:10.1007/s10640-007-9148-X

Krysiak, F., and Weigt, H. (2015). The demand side in economic models of energy markets: the challenge of representing consumer behavior. Front. Energy Res. 3: 24. doi:10.3389/ fenrg.2015.00024
Lange, I., Moro, M., and Traynor, L. (2014). Green hypocrisy?: environmental attitudes and residential space heating expenditure. Ecol. Econ. 107, 76-83. doi:10.1016/j. ecolecon.2014.07.021

Lange, P., Driessen, P. P., Sauer, A., Bornemann, B., and Burger, P. (2013). Governing towards sustainability-conceptualizing modes of governance. J. Environ. Policy Plann. 15, 403-425. doi:10.1080/1523908X.2013.769414

Lewis, J. I., and Wiser, R. H. (2007). Fostering a renewable energy technology industry: an international comparison of wind industry policy support mechanisms. Energy Policy 35, 1844-1857. doi:10.1016/j.enpol.2006.06.005

Liebe, U., and Preisendörfer, P. (2010). "Rational choice theory and the environment: variants, applications, and new trends," in Environmental Sociology, eds M. Gross and H. Heinrichs (Dordrecht: Springer), 141-157.

Linares, P., and Labandeira, X. (2010). Energy efficiency: economics and policy. J. Econ. Surv. 24, 573-592. doi:10.1111/j.1467-6419.2009.00609.x

Lindén, A. L., Carlsson-Kanyama, A., and Eriksson, B. (2006). Efficient and inefficient aspects of residential energy behaviour: what are the policy instruments for change? Energy Policy 34, 1918-1927. doi:10.1016/j.enpol.2005.01.015

Linder, S. H., and Peters, B. G. (1989). Instruments of government: perceptions and contexts. J. Public Policy 9, 35-58. doi:10.1186/1475-2875-12-342

Lipp, J. (2007). Lessons for effective renewable electricity policy from Denmark, Germany and the United Kingdom. Energy Policy 35, 5481-5495. doi:10.1016/j. enpol.2007.05.015

Loock, C., Staake, T., and Thiesse, F. (2013). Motivating energy-efficient behavior with green IS: an investigation of goal setting and the role of defaults. Mis Q. 37, 1313-1332.

Lorenzoni, I., Nicholson-Cole, S., and Whitmarsh, L. (2007). Barriers perceived to engaging with climate change among the UK public and their policy implications. Global Environ. Change 17, 445-459. doi:10.1016/j.gloenvcha.2007.01.004

Lovett, F. (2006). Rational choice theory and explanation. Ration. Soc. 18, 237-272. doi:10.1177/1043463106060155

Lutzenhiser, L. (1993). Social and behavioral aspects of energy use. Annu. Rev. Energy Environ. 18, 247-289. doi:10.1146/annurev.eg.18.110193.001335

MacInnis, D. J., and Folkes, V. S. (2010). The disciplinary status of consumer behavior: a sociology of science perspective on key controversies. J. Consum. Res. 36, 899-914. doi:10.1086/644610

March, J. G., and Olsen, J. P. (1983). The new institutionalism: organizational factors in political life. Am. Polit. Sci. Rev. 78, 734-749. doi:10.2307/1961840

Mayntz, R., Derlien, H. U., Bohne, E., Hesse, B., Hucke, J., and Müller, A. (1978). Vollzugsprobleme der Umweltpolitik. Empirische Untersuchung der Implementation von Gesetzen im Bereich der Luftreinhaltepolitik und des Gewässerschutzes. Stuttgart: Kohlhammer.

McCalley, L. T. (2006). From motivation and cognition theories to everyday applications and back again: the case of product-integrated information and feedback. Energy Policy 34, 129-137. doi:10.1016/j.enpol.2004.08.024

McDonald, S., Oates, C. J., Alevizou, P. J., Young, C. W., and Hwang, K. (2012). Individual strategies for sustainable consumption. J. Mark. Manag. 28, 445-468. doi:10.1080/0267257X.2012.658839

Meissner, M., Heinzle, S. L., and Decker, R. (2013). Not worth the extra cost? Diluting the differentiation ability of highly rated products by altering the meaning of rating scale levels. J. Consum. Behav. 12, 223-231. doi:10.1002/cb.1425

Mourik, R., and Rotmann, S. (2013). "Closing the loop - behaviour change in dsm: from theory to practice," in Analysis of case studies IEA DSM Task 24. Deliverable 2 for IEA Implementing Agreement DSM Task 24. Paris: International Energy Agency.

Nolan, J. M., Schultz, P. W., Cialdini, R. B., Goldstein, N. J., and Griskevicius, V. (2008). Normative social influence is underdetected. Pers. Soc. Psychol. Bull. 34, 913-923. doi:10.1177/0146167208316691

Nordlund, A. M., and Garvill, J. (2003). Effects of values, problem awareness, and personal norm on willingness to reduce personal car use. J. Environ. Psychol. 23, 339-347. doi:10.1016/S0272-4944(03)00037-9

Notter, D. A., Meyer, R., and Althaus, H. J. (2013). The Western lifestyle and its long way to sustainability. Environ. Sci. Technol. 47, 4014-4021. doi:10.1021/es3037548

Oikonomou, V., and Jepma, C. J. (2008). A framework on interactions of climate and energy policy instruments. Mitigation Adapt. Strateg. Global Change 13, 131-156. doi:10.1007/s11027-007-9082-9

Ölander, F., and Thøgersen, J. (2014). Informing versus nudging in environmental policy. J. Consum. Policy 37, 341-356. doi:10.1007/s10603-014-9256-2

Owens, S., and Driffill, L. (2008). How to change attitudes and behaviours in the context of energy. Energy Policy 36, 4412-4418. doi:10.1016/j.enpol.2008.09.031 
Ozanne, L. K., and Ballantine, P. W. (2010). Sharing as a form of anti-consumption? An examination of toy library users. J. Consum. Behav. 9, 485-498. doi:10.1002/cb.334

Pierre, J., and Peters, B. G. (2005). Governing Complex Societies: Trajectories and Scenarios. Basingstoke: Palgrave Macmillan.

Pollitt, M. G., and Shaorshadze, I. (2013). “The role of behavioural economics in energy and climate policy," in Handbook on Energy and Climate Change, ed. R. Fouquet (Cheltenham: Edward Elgar), 523-546.

Press, M., and Arnould, E. J. (2009). Constraints on sustainable energy consumption: market system and public policy challenges and opportunities. J. public Policy Mark. 28, 102-113. doi:10.1509/jppm.28.1.102

Reddy, A. K. (1991). Barriers to improvements in energy efficiency. Energy Policy 19, 953-961. doi:10.1016/0301-4215(91)90115-5

Rohan, M. J. (2000). A rose by any name? The values construct. Pers. Soc. Psychol. Rev. 4, 255-277. doi:10.1207/S15327957PSPR0403_4

Rudelius, W., Weijo, R., and Dodge, G. (1984). Marketing energy conservation to homeowners: an action program from public policy research. J. Public Policy Mark. 3, 149-166.

Sabatier, P. (1986). "What can we learn from implementation research?," in Guidance, Control, and Evaluation in the Public Sector. The Bielefeld Interdisciplinary Project, eds F. X. Kaufmann, G. Majone, and V. Ostrom (Berlin: De Gruyter), 312-325.

Sachs, M. L. (1993). Prospects for ending welfare as we know it. Stanford Law Policy Rev. 5, 99.

Salamon, L. M. (ed.) (2002). The Tools of Government. A Guide to the New Governance. Oxford: Oxford University Press.

SATW. (2014). Circular Economy - Improving the Management of Natural Resources. Zurich: Swiss Academies of Arts and Sciences.

Schäfer, M., Jaeger-Erben, M., and Bamberg, S. (2012). Life events as windows of opportunity for changing towards sustainable consumption patterns? J. Consum. Policy 35, 65-84. doi:10.1007/s10603-011-9181-6

Scheuthle, H., Carabias-Hütter, V., and Kaiser, F. G. (2005). The motivational and instantaneous behavior effects of contexts: steps towards a theory of goal-directed behavior. J. Appl. Soc. Psychol. 35, 2076-2093. doi:10.1111/j.1559-1816.2005. tb02210.x

Schneider, A., and Ingram, H. (1990). Behavioral assumptions of policy tools. J. Polit. 52, 510-529. doi:10.2307/2131904

Schnellenbach, J. (2012). Nudges and norms: on the political economy of soft paternalism. Eur. J. Polit. Econ. 28, 266-277. doi:10.1016/j.ejpoleco.2011.12.001

Schubert, K., and Klein, M. (2011). Das Politiklexikon. 5., aktual. Aufl. Bonn: Dietz.

Schultz, P. W., Nolan, J. M., Cialdini, R. B., Goldstein, N. J., and Griskevicius, V. (2007). The constructive, destructive and reconstructive power of social norms. Psychol. Sci. 18, 429-434. doi:10.1111/j.1467-9280.2007.01917.x

Selinger, E., and Whyte, K. P. (2012). What counts as a Nudge? Am. J. Bioeth. 12, 11-12. doi:10.1080/15265161.2011.634485

Shove, E. (1997). "18. Revealing the invisible: sociology, energy and the environment," in The International Handbook of Environmental Sociology, eds M. R. Redclift and G. Woodgate (Cheltenham: Edward Elgar), 261-273.

Shove, E. (2003). Converging conventions of comfort, cleanliness and convenience. J. Consum. Policy 26, 395-418. doi:10.1023/A:1026362829781

Shrestha, P. P., and Kulkarni, P. (2012). Factors influencing energy consumption of energy star and non - energy star homes. J. Manag. Eng. 29, 269-278. doi:10.1061/ (ASCE)ME.1943-5479.0000134

Soron, D. (2010). Sustainability, self-identity and the sociology of consumption. Sustain. Dev. 18, 172-181. doi:10.1002/sd.457

Sorrell, S., Dimitropoulos, J., and Sommerville, M. (2009). Empirical estimates of the direct rebound effect: a review. Energy Policy 37, 1356-1371. doi:10.1016/j. enpol.2008.11.026

Southerton, D., Shove, E., and Warde, A. (2001). Harried and Hurried" Time Shortage and The Co-Ordination of Everyday Life. Manchester: Manchester University. Centre for Research on Innovation and Competition.

Spaargaren, G. (2003). Sustainable consumption: a theoretical and environmental policy perspective. Soc. Nat. Resour. 16, 687-701. doi:10.1080/08941920309192

Steg, L. (2008). Promoting household energy conservation. Energy Policy 36, 4449-4453. doi:10.1371/journal.pone.0102072

Stephenson, J., Barton, B., Carrington, G., Gnoth, D., Lawson, R., and Thorsnes, P. (2010). Energy cultures: a framework for understanding energy behaviours. Energy Policy 38, 6120-6129. doi:10.1016/j.enpol.2010.05.069
Stern, P. C. (1986). Blind spots in policy analysis: what economics doesn't say about energy use. J. Policy Anal. Manag. 5, 200-227. doi:10.1002/pam.4050050202

Stern, P. C. (2000). Toward a coherent theory of environmentally significant behavior. J. Soc. Issues 56, 407-424. doi:10.1111/0022-4537.00175

Stern, P. C. (2014). Individual and household interactions with energy systems: toward integrated understanding. Energy Res. Soc. Sci. 1, 41-48. doi:10.1016/j. erss.2014.03.003

Straughan, R. D., and Roberts, J. A. (1999). Environmental segmentation alternatives: a look at green consumer behavior in the new millennium. J. Consum. Mark. 16, 558-575. doi:10.1108/07363769910297506

Sunstein, C. (2015). "Behavioral economics, consumption, and environmental protection," in Handbook on Research in Sustainable Consumption, eds L. Reisch and J. Thøgersen (Cheltenham: Edward Elgar), 313-327.

Sunstein, C., and Reisch, L. (2013). Automatically green: behavioral economics and environmental protection. Harv. Environ. Law Rev. 38, 127-158.

Susskind, A. M. (2014). Guests' reactions to in-room sustainability initiatives an experimental look at product performance and guest satisfaction. Cornell Hosp. Q. 55, 1-11. doi:10.1177/1938965514533744

Sütterlin, B., Brunner, T. A., and Siegrist, M. (2011). Who puts the most energy into energy conservation? A segmentation of energy consumers based on energy-related behavioral characteristics. Energy Policy 39, 8137-8152. doi:10.1016/j. enpol.2011.10.008

Thaler, R. H., and Sunstein, C. R. (2008). Nudge: Improving Decisions About Health, Wealth, and Happiness. New Haven, CT: Yale University Press.

Thøgersen, J. (2005). How may consumer policy empower consumers for sustainable lifestyles? J. Consum. Policy 28, 143-178. doi:10.1007/s10603-005-2982-8

Tiefenbeck, V., Staake, T., Roth, K., and Sachs, O. (2013). For better or for worse? Empirical evidence of moral licensing in a behavioral energy conservation campaign. Energy Policy 57, 160-171. doi:10.1016/j.enpol.2013.01.021

Vallgårda, S. (2012). Nudge - A new and better way to improve health? Health Policy 104, 200-203. doi:10.1016/j.healthpol.2011.10.013

Van den Bergh, J. C. (2008). Environmental regulation of households: an empirical review of economic and psychological factors. Ecol. Econ. 66, 559-574. doi:10.1016/j. ecolecon.2008.04.007

Van den Bergh, J. C. (2011). Energy conservation more effective with rebound policy. Environ. Resour. Econ. 48, 43-58. doi:10.1007/s10640-010-9396-Z

Van Raaij, W. F., and Verhallen, T. M. (1983). A behavioral model of residential energy use. J. Econ. Psychol. 3, 39-63. doi:10.1016/0167-4870(83)90057-0

Veblen, T. (2007). The Theory of the Leisure Class: An Economic Study of Institutions. Oxford: Oxford University Press. first published 1899.

Vedung, E. (2007). "Policy-instruments: typologies and theories”, in Carrots, Sticks \& Sermons. Policy Instruments and Their Evaluation, eds M. L. Bemelmans-Videc, R. C. Rist, and E. Vedung (New Brunswick, NJ: Transaction Publishers), 21-58.

Voß, J. P., Bauknecht, D., and Kemp, R. (eds) (2006). Reflexive Governance for Sustainable Development. Cheltenham: Edward Elgar Publishing.

Walker, G. (2014). The dynamics of energy demand: change, rhythm and synchronicity. Energy Res. Soc. Sci. 1, 49-55. doi:10.1016/j.erss.2014.03.012

Warde, A. (2005). Consumption and theories of practice. J. Consum. Cult. 5, 131-153. doi:10.1177/1469540505053090

Wilk, R. (2002). Consumption, human needs, and global environmental change. Global Environmental Change 12(1), 5-13. doi:10.1016/S0959-3780(01)00028-0.

Wilson, C., and Dowlatabadi, H. (2007). Models of decision making and residential energy use. Annu. Rev. Environ. Resour. 32, 169-203. doi:10.1146/annurev. energy.32.053006.141137

Conflict of Interest Statement: The authors declare that the research was conducted in the absence of any commercial or financial relationships that could be construed as a potential conflict of interest.

Copyright ( 2015 Burger, Bezençon, Bornemann, Brosch, Carabias-Hütter, Farsi, Hille, Moser, Ramseier, Samuel, Sander, Schmidt, Sohre and Volland. This is an open-access article distributed under the terms of the Creative Commons Attribution License (CC BY). The use, distribution or reproduction in other forums is permitted, provided the original author(s) or licensor are credited and that the original publication in this journal is cited, in accordance with accepted academic practice. No use, distribution or reproduction is permitted which does not comply with these terms. 